\title{
Double deprotonation of pyridinols generates potent organic electron donor initiators for haloarene-arene coupling
}

\author{
Joshua P. Barham, Graeme Coulthard, Ryan G. Kane, Nathan Delgado, Matthew P. John, and John A. \\ Murphy*
}

\begin{abstract}
Transition metal-free couplings of haloarenes with arenes, triggered by the use of alkali metal alkoxides in the presence of an organic additive, are receiving significant attention in the literature. Most of the known organic additives effect coupling of iodoarenes, but not bromoarenes, to arenes. Recently Kwong showed that 2pyridinecarbinol 11 extends the reaction to aryl bromides. This paper investigates the mechanism, and reports evidence for dianions derived from 11 as electron donors to initiate the reaction. It also proposes routes by which electron-poor benzoyl derivatives can be transformed into electron donors to initiate these reactions.
\end{abstract}

Transition metal-free dehalogenative couplings between haloarenes and arenes are attracting significant attention from the chemists. Reactions are mediated by a base (typically $\mathrm{KO} \mathrm{Bu})$ and an organic additive. ${ }^{1-15}$ The mechanism for these reactions features base-promoted homolytic aromatic substitution (BHAS).$^{16}$ Here, an aryl radical 2 adds to the arene partner to yield radical 3 . Deprotonation yields radical anion 4 which can propagate the chain through electron transfer to aryl halide $\mathbf{1}$, simultaneously releasing biaryl product $\mathbf{5}$. The majority of reports are concerned with the couplings of aryl iodides. How the aryl radical $\mathbf{2}$ is generated in the first place (initiation) has not been extensively explored. ${ }^{14,15,17,18}$

A host of reported organic additives (amino acids, alcohols, 1,2diamines) were analysed in one study by our group to probe the mechanism of initiation. ${ }^{18}$ We proposed a simple unifying mechanism for these additives, in each case involving formation of an organic electron donor. Both neutral electron donors like 6 and simple enolates e.g. 7,8 can activate aryl iodides under facile SET reactions. The key structural component of the electron donor is an alkene that is substituted by one or more electron-donating groups. Forming the aryl radicals in this way initiates the chain reaction shown in Scheme 1.

Scheme 1 involves two electron transfer steps (i) in initiation and (ii) in propagation, converting radical anion 4 to product 5 . A crucial question relates to which electron donor is the bottleneck. Specifically, if the initiating electron donor is made stronger so that it can initiate aryl bromides, will radical anion $\mathbf{4}$ be a strong enough donor to propagate the chain? An answer to this came in a recent breakthrough with the report that the additive, 2pyridinecarbinol 11, initiates coupling of aryl bromides to arenes under mild conditions. ${ }^{4}$ Bromoarenes 9 coupled efficiently in the presence of this additive, giving rise to biaryls $\mathbf{1 0}$ in moderate to high $(43-88 \%)$ yields (Scheme 2). Clearly, a more reactive

[a] J. P. Barham, Dr. G. Coulthard, R. G. Kane, N. Delgado, Prof. Dr. J. A. Murphy

WestCHEM, Department of Pure and Applied Chemistry

University of Strathclyde

295 Cathedral Street, Glasgow G1 1XL (UK)

E-mail: john.murphy@strath.ac.uk

[b] J. P. Barham, Dr. M. P. John

GlaxoSmithKline Medicines Research Centre

Gunnels Wood Road, Stevenage SG1 2NY (UK) electron donor than normal is present to initiate the reaction and following initiation, the reaction can indeed be sustained by electron transfer from 4.

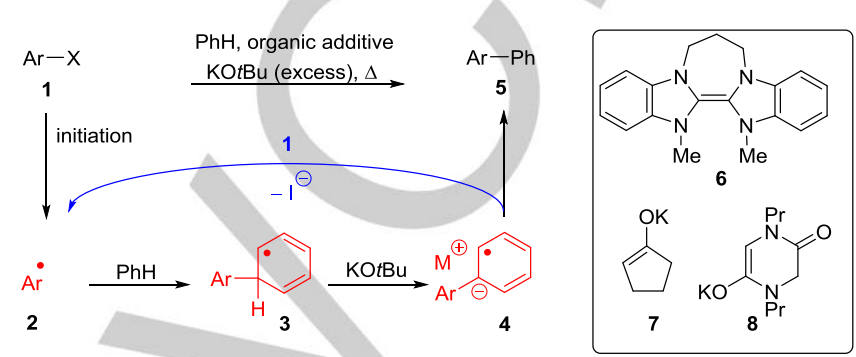

Scheme 1. Radical Chain Mechanism depicting BHAS; initiation by organic electron donors e.g. 6-8.

In our hands, the coupling of 4-bromotoluene $9(\mathrm{R}=\mathrm{p}-\mathrm{Me})$ to benzene under Kwong's conditions ( 2 equiv. KOtBu, $10 \mathrm{~mol} \%$ $11,80{ }^{\circ} \mathrm{C}$ for $24 \mathrm{~h}$ in benzene solvent) worked as stated and gave the biaryl product $10(\mathrm{R}=p-\mathrm{Me})$ in $60 \%$ isolated yield, ${ }^{4}$ so we resolved to probe the mechanism of action of $\mathbf{1 1}$.

Although initiation routinely occurs through formation of an organic electron donor, ${ }^{8,18}$ a second, more sluggish route to initiation can occur when the substrate can form a benzyne, and this background mechanism can cloud the picture. Kwong et al. observed no coupling of 4-bromotoluene to benzene in the absence of additive $11,{ }^{4}$ suggesting initiation via benzyne was not occurring under their conditions. Our mechanistic studies would benefit from freedom to explore a range of conditions, and to guard against side-reactions with benzynes, we chose coupling substrates $\mathbf{1 2 a}, \mathbf{b}$ which completely rule out benzyne formation, allowing us to compare additives and confidently focus solely on their ability to form electron donors in situ. ${ }^{17,18}$
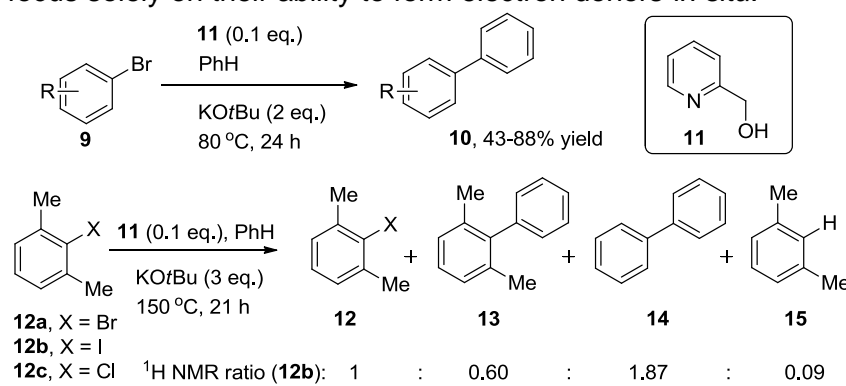

Scheme 2. Top: Coupling of bromoarenes 9 to benzene in the presence of additive 11 under Kwong's conditions. Bottom: Coupling of electron-transfer reporters 12 affording biaryls 13 and 14

Competent electron donors convert additives $12 \mathbf{a}, \mathbf{b}$ to the corresponding aryl radical, which, because of its steric bulk undergoes competing signature reactions, namely (i) addition to benzene, leading to substituted biphenyl 13 and (ii) hydrogen abstraction from benzene affording the volatile $m$-xylene, 15 , as well as a phenyl radical that leads to biphenyl $\mathbf{1 4}$ 
Because of the steric properties of its derived aryl radical, the yields from substrates $\mathbf{1 2 a , b}$ are always lower than for simple substrates like the 4-bromotoluene reported above, but the mechanistic information provided is invaluable. To compensate for the lower reactivity of $\mathbf{1 2}$, we used harsher conditions (3 equiv. $\mathrm{KOtBu}, 10 \mathrm{~mol} \% 11,150{ }^{\circ} \mathrm{C}$ for $21 \mathrm{~h}$ in benzene solvent). Substrate 12b (Table 1, Entry 3 ) reacted more efficiently than the bromide 12a (Table 1, Entry 2) affording the combined biaryls (13 and 14) as the major component, and so we adopted $12 b$ as our routine substrate. The formation of products 13 and 14 confirmed that electron transfer was occurring, following generation of an organic electron donor from 11 (Scheme 1).

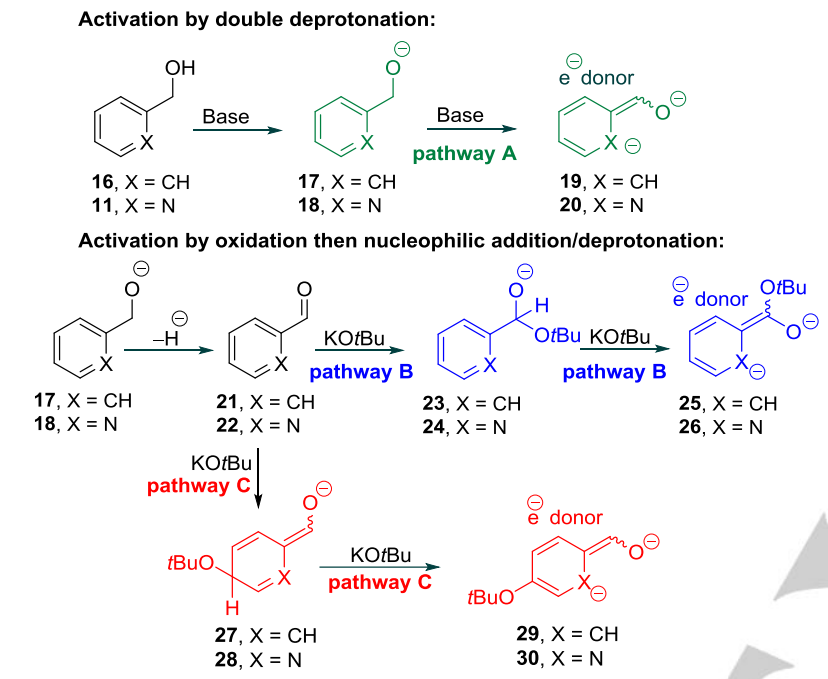

Scheme 3. Proposed mechanistic pathways for activation of additives

We considered how reaction of $\mathrm{KOtBu}$ with $\mathbf{1 1}$ could form an organic electron donor. Chain reaction initiation is possible with very low concentrations of active species, allowing consideration of intermediates that would be ruled out of stoichiometric synthetic pathways One mechanism ${ }^{18}$ could involve double deprotonation of 11 by $\mathrm{KOtBu}$, firstly at the alcohol and secondly at the benzylic position (Scheme 3, pathway A) to afford 20. An alternative mechanism could involve oxidation of the pyridinol anion 18 via hydride loss. ${ }^{18}$ Hydride loss from primary and secondary alcohols has been demonstrated under the conditions of the coupling reactions. The resulting aromatic aldehyde 22 would not be an electron donor, of course, but it could be susceptible to nucleophilic attack either at the aldehyde function (Scheme 3) to afford $\mathbf{2 4}$ or at the aromatic ring, presumably at the ortho- position or para- position (to give 28). Deprotonation of 24 and 28 respectively would give rise to organic donors 26 and 30. To shed light on the mechanisms of initiation of the 2pyridinecarbinol (11), a number of analogues (Figure 1) were employed as additives in the coupling reaction of $\mathbf{1 2}$. Heating $\mathbf{1 2}$ in benzene with $\mathrm{KOtBu}$ ( 3 equiv.) and additive ( 0.1 equiv.) afforded 13, 14 and 15. Products are clearly identified in the ${ }^{1} \mathrm{H}$ NMR spectrum of the reaction mixture allowing facile determination of the ratio of $12: 13: 14: 15$. In key cases, biaryls 13 and 14 were isolated by chromatography (as an inseparable mixture) and yields determined or, alternatively, quantified by the use of an internal standard. All reactions were performed using the same scale of $12,(116 \mathrm{mg}, 0.5 \mathrm{mmol}$ ) under identical conditions of temperature, numbers of reagent equivalents, solvent volumes and time. For key comparisons of additives, a pair of reactions was run side-by-side and the reaction pair repeated.

Blank reactions without additive (Table 1, Entry 1) confirmed the non-reactivity of $\mathbf{1 2}$ due to the inability of KOtBu to act as an electron donor to haloarenes, as evidenced previously. ${ }^{17-20}$ To investigate the effect of blocking the benzylic position of 2 pyridinecarbinol 11, gem-dimethyl additive $\mathbf{3 1}$ was tested under the reaction conditions side-by-side with 11 (the reactions were repeated to confirm reproducibility, Table 1, Entries 3-4). It is clearly seen that the gem-dimethyl additive $\mathbf{3 1}$ is not capable of effecting the coupling, consistent with an important role for benzylic $\mathrm{C}-\mathrm{H}$ deprotonation. ${ }^{21}$ Blocking the hydroxyl proton as its methyl ether in additive $\mathbf{3 2}$ halted the reaction, and removing the hydroxyl group as in additive $\mathbf{3} 3$ resulted in significant loss of reactivity (Table 1, Entries 5-6). These results strongly suggest that double deprotonation (Scheme 3, pathway A) is the major pathway of electron donor formation from 11.

Additives:

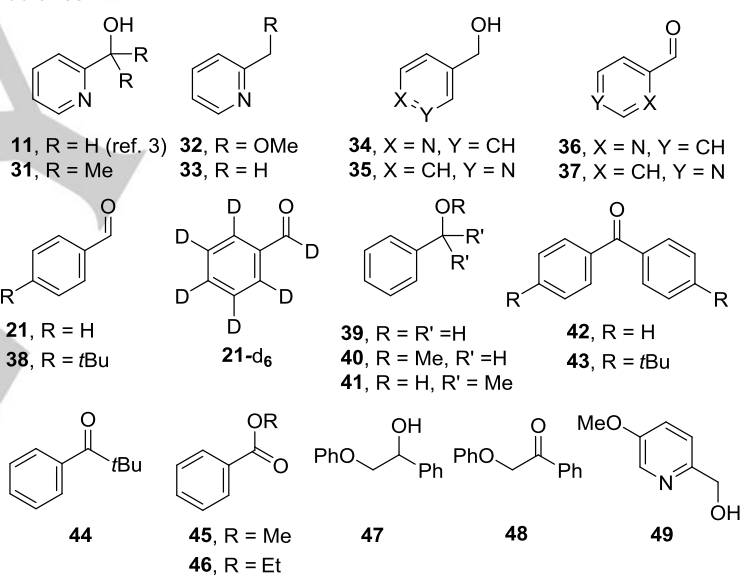

Figure 1. Unusual organic additives that facilitate coupling of haloarenes to arenes.

Next, 4-pyridinecarbinol 34 and 3-pyridinecarbinol 35 (Table 1, Entries 7-8) were investigated and displayed a decrease in reactivity in that order. Upon deprotonation, 11 can delocalise its negative charge onto the pyridine $\mathrm{N}$-atom whereas 35 cannot. Deprotonation at the benzylic position was confirmed when $\mathbf{1 1}$ was treated (in the absence of 12) with $\mathrm{KOtBu}$ (2 equiv.) in $\mathrm{PhH} / \mathrm{D}_{2} \mathrm{O}(1: 1)$ at $130{ }^{\circ} \mathrm{C}$ for $18 \mathrm{~h}$, resulting in deuteration at the benzylic position (see Supporting Information). Next, 2pyridinecarboxaldehyde 36 and 4-pyridinecarboxaldehyde 37 were tested (Table 1, Entries 9-10) and resulted in appreciably lower reactivity than the corresponding carbinols $\mathbf{1 1}$ and $\mathbf{3 4}$. If the pyridinecarbinols underwent hydride loss (as evidenced for other alcohol additives) ${ }^{18}$ as the main pathway for generating single electron donors, then the pyridinecarboxaldehyde 
additives (36 and 37 ) should be more reactive than the pyridinecarbinol additives (11 and $\mathbf{3 4}$ ).

Table 1: Coupling reactions of 2,6-dimethylhalobenzenes 12a,b with benzene, facilitated by organic additives

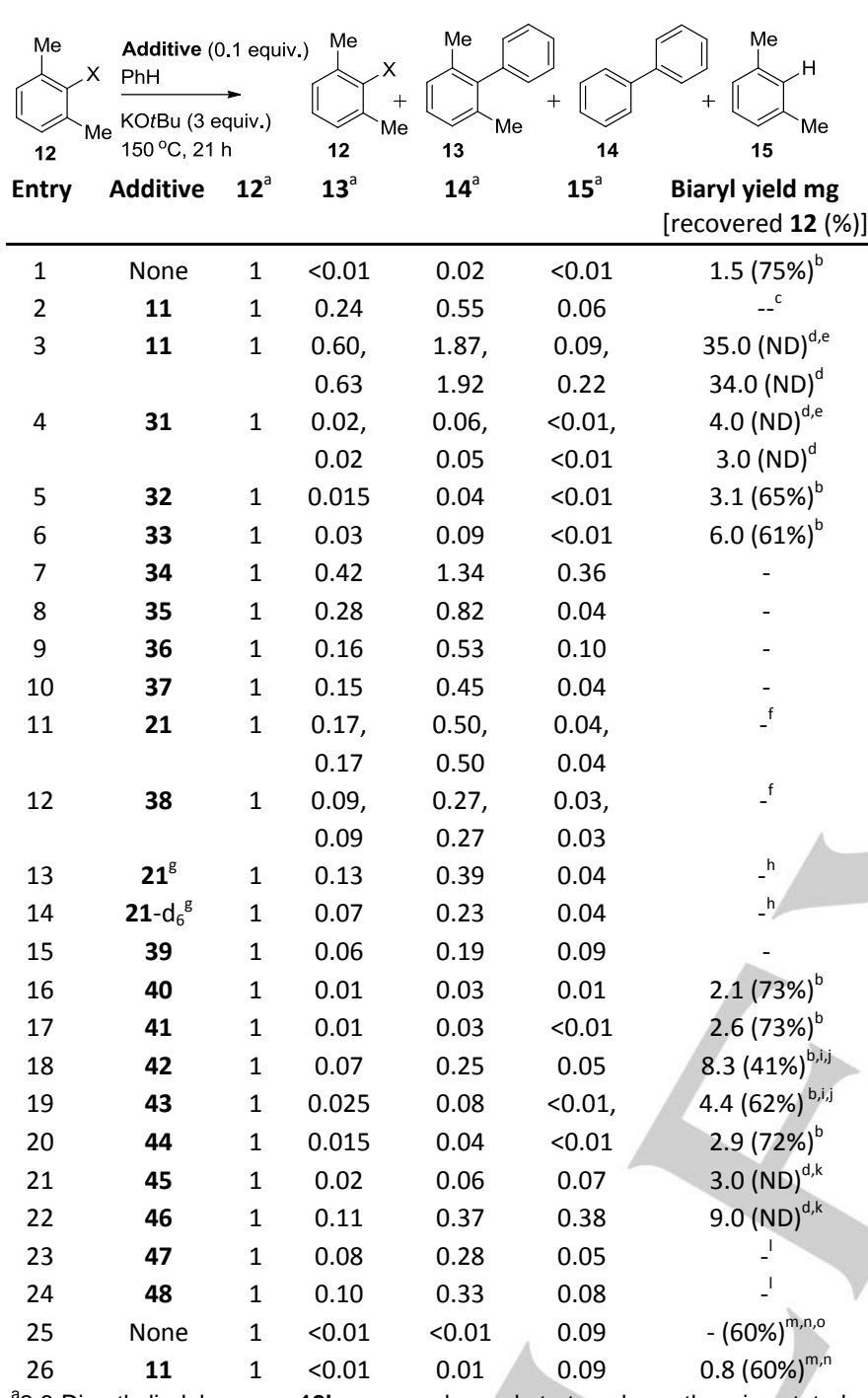

${ }^{a} 2,6$-Dimethyliodobenzene $\mathbf{1 2 b}$ was used as substrate unless otherwise stated. Ratios determined by ${ }^{1} \mathrm{H}$ NMR of reaction mixture (see Supporting Information). ${ }^{b}$ Yield $(\mathrm{mg})$ of combined biaryls (13 and 14), determined by 1,3,5trimethoxybenzene $(10 \mathrm{~mol} \%)$ as an internal standard in NMR, yield (\%) of returned 12 shown in parenthesis. ${ }^{c} 2,6$-Dimethylbromobenzene 12a was used as substrate. "'Isolated' yield $(\mathrm{mg})$ of combined biaryls (13 and 14), inseparable by chromatography. ${ }^{\mathrm{e}, \mathrm{f}}$ Reactions were conducted side-by-side under identical conditions and the reaction pair was repeated. ${ }^{9}$ Prepared sideby-side by CAN oxidation of toluene or toluene- $d_{6}$ (see Supporting Information). $h, i, k, l, n$ The two reactions were conducted side-by-side under identical conditions. ${ }^{\mathrm{j}}$ Average of three runs. ${ }^{\mathrm{m}} 2,6$-Dimethylchlorobenzene $12 \mathrm{c}$ was used as substrate. ${ }^{\circ}$ Biaryls were not detected by ${ }^{1} \mathrm{H}$ NMR

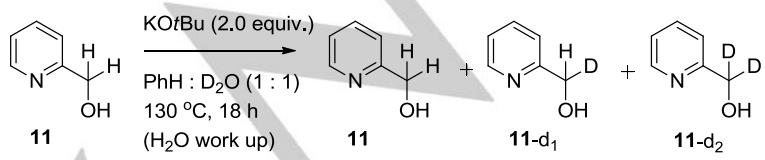

Scheme 4. KOtBu-mediated benzylic deuteration of 2-pyridincarbinol (11) in the presence of $\mathrm{D}_{2} \mathrm{O}$.
To further probe mechanisms, benzaldehyde 21 and corresponding substituted or deuterated analogues were subjected to the reaction conditions. Benzaldehyde $\mathbf{2 1}$ was tested side-by-side with 4-(tert-butyl)benzaldehyde 38 (the reaction pair was repeated to confirm reproducibility, Table 1, Entries 11-12) demonstrating that blocking the para-position halved the conversions. ${ }^{4}$

To investigate the effect of deuteration, benzaldehyde- $d_{6}\left(21-d_{6}\right)$ synthesised from toluene- $d_{8}$ was compared side-by-side (Table 1, Entries 13-14) with benzaldehyde 21 (synthesised in exactly the same way from toluene, ${ }^{24}$ see Supporting Information). Deuteration halved the conversion seen with benzaldehyde 21, indicating that formation of the initiator likely involves breaking of a $\mathrm{C}-\mathrm{H} / \mathrm{C}-\mathrm{D}$ bond in the rate-determining step.

An interesting observation is that benzyl alcohol $\mathbf{3 9}$ gave rise to lower reactivity than 21 (Table 1, Entry 15), contrasting with the difference in reactivity between pyridinecarbinols (11 and $\mathbf{3 4}$ ) and their corresponding pyridinecarboxaldehydes (36 and 37). The electron-deficiency of $\mathbf{1 1}, \mathbf{3 4}$ and $\mathbf{3 5}$ renders them more susceptible to the double deprotonation mechanism (Scheme 3, pathway A) than 39. Oxidation followed by nucleophilic addition/deprotonation (Scheme 3, pathways B and C) may be the preferred mechanism for electron donor formation from 39 , hence reactivity is enhanced with $\mathbf{2 1}$, which is already an oxidation state higher. This was confirmed through use of additives $\mathbf{4 0}$ and $\mathbf{4 1}$ (Entries 16-17), which are blocked to both double deprotonation and oxidation, thereby halting the reaction. To investigate whether an aldehyde function was required, benzophenone 42 was tested side-by-side with 4,4'-di-tertbutylbenzophenone 43 (Table 1, Entries 18-19). Benzophenone 42 gave similar reactivity to benzyl alcohol $\mathbf{3 9}$ and the fact that coupling was observed supports the proposal for the pathway involving nucleophilic addition to the arene followed by deprotonation (Scheme 3, pathway C). Furthermore, blocking the para-positions to nucleophilic attack in the form of additive 43 halved the reactivity, mirroring the difference in reactivity between additives $\mathbf{2 1}$ and $\mathbf{3 8}$.

To explore further, we employed pivalophenone 44. ${ }^{1} \mathrm{H}$ NMR (see Supporting Information) indicates that $\mathbf{4 4}$ experiences diminished conjugation between the carbonyl and the arene. Hence we predicted that the nucleophilic addition/deprotonation mechanism (Scheme 3, pathway C) would be less available to pivalophenone 44 . In line with this, subjecting $\mathbf{4 4}$ to the coupling reaction of $\mathbf{1 2}$ gave no more reactivity than the blank reaction (Table 1, Entry 20).

Overall, benzophenone-type additives 42 and 43 were less effective than benzaldehyde-type additives $\mathbf{2 1}$ and $\mathbf{3 8}$ where the aldehyde function was available to react. To further probe the role of benzoyl groups, esters $\mathbf{4 5}$ and $\mathbf{4 6}$ were studied side-byside (Table 1, Entries 21-22). Whilst methyl benzoate 45 provided results that were similar to the blank reaction, we were surprised at appreciably higher reactivity for 46. We rationalised that transesterification under the reaction conditions would liberate ethoxide (Scheme 5 ) and $\mathrm{Bi}^{11}$ reported ethanol as a good promoter of KOtBu-mediated cross couplings. Ethoxide would form the enolate of acetaldehyde, which can act as electron donor, through the previously reported mechanism. ${ }^{9}$ When ethyl benzoate $\mathbf{4 6}$ was subjected at RT to the reaction conditions in the absence of $\mathbf{1 2},{ }^{25}$ full conversion of ethyl 
benzoate occurred, forming tert-butyl ester $\mathbf{5 0}$ as the sole product (see Supporting Information). Additives $\mathbf{4 7}$ and $\mathbf{4 8}$ were employed in the coupling reaction of 12 (Table 1, Entries 23-24). Alcohol $\mathbf{4 7}$ initiated the reaction (with similar efficacy to additives 39 and 42), rationalised by oxidation to ketone 48 . This was confirmed when $\mathbf{4 8}$ gave similar (if marginally higher) activity.

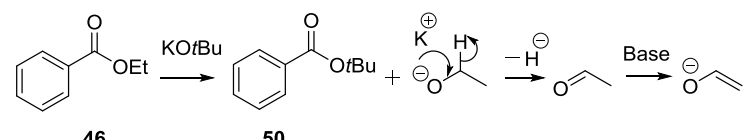

Scheme 5. Mode of activation for ethyl benzoate 46 .

In this study, it is double-deprotonation of 2-pyridinecarbinol $\mathbf{1 1}$ which forms the most potent electron donor (20), which can initiate reactions of bromoarenes. However, it is ineffective at initiating reactions of chloroarenes. When 2,6dimethylchlorobenzene 12c was treated with 11 under our conditions, only trace levels of biaryls were observed; the reaction was run side-by-side with a blank reaction where $\mathbf{1 1}$ was omitted (Table 1, entries 25 and 26). Our findings mirrored Kwong's when 4-chlorotoluene was used under their conditions, giving a very low $8 \%$ yield of $\mathbf{1 0}(\mathrm{R}=p$-Me) by internal standard. An analogue of 11 with an additional alkoxy-substituent (49) (which mimics dianion $\mathbf{3 0}$ upon double deprotonation) was no more effective. Cyclic voltammetry studies suggest that the thermodynamics for the reduction of chloroarenes by these dianions are favourable (see Supporting Information). ${ }^{26}$ Similarly, the oxidation potentials for biphenyl radical anions (e.g. 4$)^{27}$ are sufficiently negative to reduce chloroarenes, so that it is the kinetics of the chloroarene reactions (probably associated with the loss of chloride ion from the chloroarene radical anion) that constitute the bottleneck.

To conclude, reaction of 2-pyridinecarbinol $\mathbf{1 1}$ with $\mathrm{KO}$ tBu affords a potent electron donor, which facilitates coupling of bromobenzenes to arenes. ${ }^{4}$ Double-deprotonation plays a key role in coupling reactions initiated by $\mathbf{1 1}$. It identifies a secondary pathway for conversion of benzylic alcohols into electron donors, involving initial in situ oxidation of the alcohol. Understanding the initiation of transition metal-free cross coupling reactions is key to unlocking milder conditions and to coupling more challenging substrates in these reactions.

\section{Acknowledgements}

We thank the University of Strathclyde and GlaxoSmithKline for funding. We thank $\mathrm{Dr}$ Len Berlouis for help with cyclic voltammetry. Mass spectrometry data were acquired at the ESPRC UK National Mass Spectrometry Facility at Swansea University.

Keywords: pyridinecarbinol - reduction - electron transfer • radical chain $\cdot$ electron donor $\cdot$ coupling

\section{References}

[1] S. Yanagisawa, K. Ueda, T. Taniguchi, K. Itami, Org. Lett. 2008, 10 4673-4676

[2] C.-L. Sun, H. Li, D.-G Yu, M. Yu, X. Zhou, X.-Y Lu, K. Huang, S.-F. Zheng, B.-J. Li, Z.-J. Shi, Nat. Chem. 2010, 2, 1044-1049.

[3] W. Liu, H. Cao, H. Zhang, H. Zhang, K. H. Chung, C. He, H. Wang, F. Y. Kwong, A. Lei, J. Am. Chem. Soc. 2010, 132, 16737-16740.

[4] Y. Wu, P. Y. Choy, F. Y. Kwong, Org. Biomol Chem. 2014, 12, 6820-6823.

[5] E. Shirakawa, K.-I. Itoh, T. Higashino, T. Hayashi, J. Am. Chem. Soc. 2010, 132, 15537-15539.

[6] M. Rueping, M. Leiendecker, A. Das, T. Poisson, L. Bui, Chem Commun. 2011, 47, 10629-10631.

[7] H. Liu, B. Yin, Z. Gao, Y. Li, H. Jiang, Chem. Commun. 2012, 48, 2033-2035

[8] D. S. Roman, Y. Takahashi, A. B. Charette, Org. Lett. 2011, 13, 3242-3245.

[9] S. De, S. Ghosh, S. Bhunia, J. A. Shiekh, A. Bisai, Org. Lett, 2012, 14 4466-4469.

[10] K. Tanimoro, M. Ueno, K. Takeda, M. Kirihata, S. Tanimori, J. Org Chem. 2012, 77, 7844-7849.

[11] W. Liu, F. Tian, X. Wang, H. Yu, Y. Bi, Chem. Commun. 2013, 49, 2983-2985

[12] W.-C. Chen; Y.-C. Hsu, W.-C. Shih, C.-Y. Lee, W.-H. Chuang, Y.-F. Tsai, P. P.-Y. Chen, T.-G. Ong, Chem. Commun. 2012, 48, 6702-6704.

[13] S. Sharma, M. Kumar, V. Kumar, N. Kumar, Tetrahedron Lett. 2013, 54, 4868-4871.

[14] J. Cuthbertson, V. J. Gray, J. D. Wilden, Chem. Commun. 2014, 50, 2575-2578.

[15] H. Yi, A. Jutand, A. Lei, Chem. Commun. 2015, 51, 545-548.

[16] A. Studer, D. P. Curran, Angew. Chem. Int. Ed. 2011, 50, 5018-5022.

[17] S. Zhou, G. M. Anderson, B. Mondal, E. Doni, V. Ironmonger, M. Kranz, T. Tuttle, J. A. Murphy, Chem. Sci. 2014, 5, 476-482.

[18] S. Zhou, E. Doni, G. M. Anderson, R. G. Kane, S. W. MacDougall, V. M. Ironmonger, T. Tuttle, J. A. Murphy, J. Am. Chem. Soc. 2014, 136, 17818-17826.

[19] M. P. Drapeau, I. Fabre, L. Grimaud, I. Ciofini, T. Ollevier, M. Taillefer, Angew. Chem. Int. Ed. 2015, 54, 10587-10591.

[20] The blank reaction was performed under the published conditions, ${ }^{18}$ the ratio of $12: 13: 14: 15$ was $1:<0.01:<0.01:<0.01$ which corresponded with a biaryl yield of $0.3 \mathrm{mg}$ (using $10 \mathrm{~mol} \%$ 1,3,5-trimethoxybenzene as an internal standard), consistent with previous findings. ${ }^{18}$ It might be imagined that this background reactivity should be 0 rather than $<0.5$ $\mathrm{mg}$, but it is clear that a very small amount of background reaction arises from other less prevalent pathways. In this regard, pyridines + $\mathrm{KO}$ Bu afford electron donors, ${ }^{17}$ although the process is very inefficient, and requires pyridine in great excess as solvent to work well. ${ }^{7}$

[21] The possibility for additives such as $\mathbf{1 1}$ initiating the coupling reactions by complexing potassium $t$-butoxide to yield an electron donor ${ }^{2,5,14,15}$ is inconsistent with the non-reactivity of additive 31 .

[22] Although deprotonated forms of both $\mathbf{1 1}$ and $\mathbf{3 4}$ can delocalise their charges onto the pyridine $\mathrm{N}$-atom, the difference in reactivity observed may be due to enhanced complexation of $\mathrm{K}^{+}$afforded by $\mathbf{1 1}$ (compared to 34 ), increasing the acidity of its hydroxyl and benzylic protons.

[23] Blocking the para-position in the form of additives $\mathbf{3 8}$ and $\mathbf{4 3}$ still gave some reactivity over the blank reaction. This suggests that attack at the aldehyde function and/or ortho- position of $\mathbf{3 8}$ are important. Similarly, attack at the ortho- position of $\mathbf{4 3}$ might occur.

[24] L. Zhang, X. Bi, X. Guan, X. Li, Q. Liu, B.-D. Barry, P. Liao, Angew. Chem. Int. Ed. 2013, 52, 11303-11307.

[25] V. Vasin, V. Razin, Synlett 2001, 5, 658-660.

[26] Cyclic voltammetry of 12c gave $E^{\mathrm{p}}=-2.60 \mathrm{~V}$ vs. SCE. Cyclic voltammetry of $\mathbf{3 6}$ gave $E^{\mathrm{P}}=$ (i) $-1.55 \mathrm{~V}$, (ii) $<-2.50 \mathrm{~V}$ vs. SCE.

[27] Pérez, H.; Melero, C.; Guijarro, A.; Yus, M. Tetrahedron, 2009, 65, 10769-10783 
Entry for the Table of Contents (Please choose one layout)

Layout 1:

COMMUNICATION<smiles>[X]c1ccccc1</smiles>

$\mathrm{KOtBu},(3$ equiv)

$\mathrm{PhH}, 150^{\circ} \mathrm{C}$

11 or 31

(0.1 equiv), $21 \mathrm{~h}$

$$
\text { 31, INEFFECTIVE }
$$

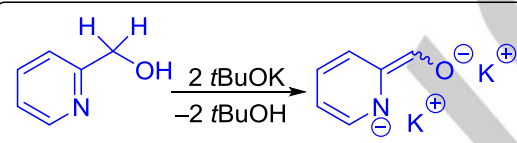

11, EFFECTIVE

coupling additive

20, PROPOSED in situ electron donor
Joshua P. Barham, Graeme Coulthard, Ryan G. Kane,

Nathan Delgado, Matthew $P$. John, John A. Murphy*

Page No. - Page No.

Double Deprotonation of Pyridinols Generates Potent Organic Electron Donor Initiators for Haloarene-arene Coupling 


\section{SUPPLEMENTARY INFORMATION FILE}

\section{TABLE OF CONTENTS}

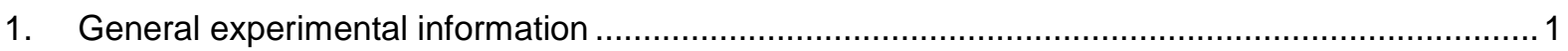

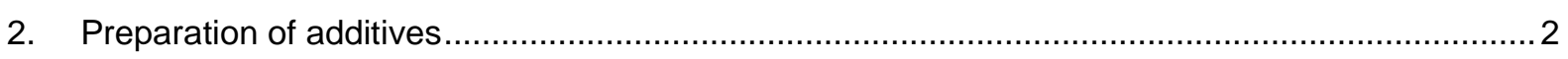

3. Transesterification of ethyl benzoate with potassium tert-Butoxide .............................................. 4

4. KOtBu-mediated benzylic deuteration of 2-pyridinecarbinol in the presence of $\mathrm{D}_{2} \mathrm{O}$...................6

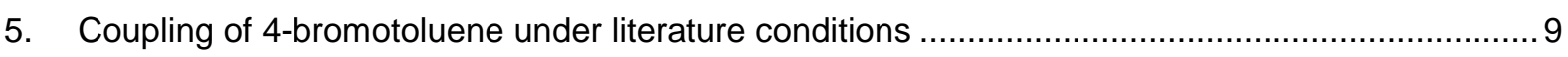

6. General procedures for coupling reactions of 2,6-dimethylhalobenzenes ....................................

7. Representative ${ }^{1} \mathrm{H}$ NMR Spectra from coupling reactions of 2,6-dimethyliodobenzene................11

8. ${ }^{1} \mathrm{H}$ NMR and I.R. spectral comparison of pivalophenone and acetophenone................................ 13

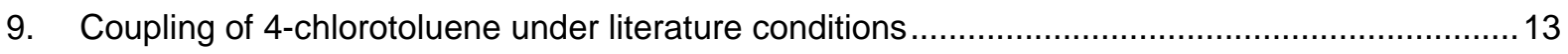

10. Synthesis of (5-methoxypyridin-2-yl)methanol for use as an additive in couplings of chloroarenes 14

11. Coupling of 4-chlorotoluene using (5-methoxypyridin-2-yl)methanol as an additive .15

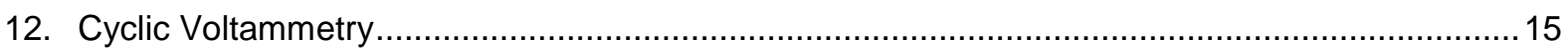

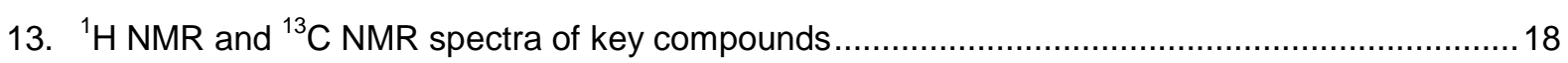

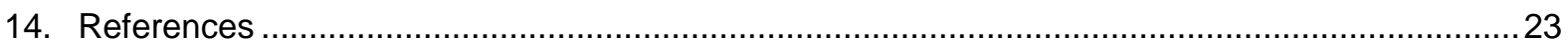

\section{GenERAL EXPERIMENTAL INFORMATION}

Unless stated otherwise, reactions were performed in oven-dried pressure tubes in a nitrogen-filled glove box (Innovative Technology Inc., U.S.A.) using dry, degassed solvents. Heating was achieved through use of a silicone oil bath. Diethyl ether, tetrahydrofuran, dichloromethane and hexane were dried with a Pure-Solv 400 solvent purification system by Innovative Technology Inc., U.S.A. For purposes of thin layer chromatography (TLC), POLYGRAM ${ }^{\circledR}$ SIL G/uv254 silica plates were used, with UV light $(\lambda=254 \mathrm{~nm})$ and phosphomolybdic acid stain used for visualisation. Purification was achieved by column chromatography using silica gel 60 (200-400 mesh). ${ }^{1} \mathrm{H}$ and ${ }^{13} \mathrm{C}$ NMR data were collected using a Bruker Avance 400 Ultrashield instrument $\left(400 \mathrm{MHz}, 61 \mathrm{MHz}\right.$ and $100 \mathrm{MHz}$ for ${ }^{1} \mathrm{H}$ NMR, ${ }^{2} \mathrm{H}$ NMR and ${ }^{13} \mathrm{C}$ NMR, respectively). Data were manipulated using ACD/SpecManager version 12.5. Reference values for residual solvents were taken as $\delta=7.27\left(\mathrm{CDCl}_{3}\right)$ for ${ }^{1} \mathrm{H} \mathrm{NMR} ; \delta=77.00$ ppm $\left(\mathrm{CDCl}_{3}\right)$ for ${ }^{13} \mathrm{C}$ NMR. Multiplicities for coupled signals were denoted as: $\mathrm{s}=$ singlet, $d=$ doublet, $\mathrm{t}=$ triplet, $\mathrm{q}=$ quartet, $\mathrm{m}=$ multiplet, $\mathrm{br} .=$ broad, apt. = apparent and $\mathrm{dd}=$ double doublet etc. Coupling constants $(\mathcal{J})$ are given in $\mathrm{Hz}$. Infra-Red spectra were recorded on a Shimadzu FT-IR Spectrophotometer (Model IRAffinity-1) with a MIRacle Single Reflection Horizontal ATR Accessory as a thin film unless otherwise stated. High resolution mass spectra were recorded at the EPSRC National Mass Spectrometry Service Centre in Swansea on a LTQ Orbitrap XL using Atmospheric Pressure Chemical Ionisation (APCl) or High Resolution Nano-Electrospray (HNESP) using Electrospray lonisation (ESI); masses observed are accurate to within $5 \mathrm{ppm}$. All reagents were purchased from Sigma-Aldrich of Alfa Aesar and used as supplied. 
Cyclic voltammetry was conducted using a three-electrode setup consisting of a platinum wire working electrode $(\mathrm{d}=1.0 \mathrm{~mm})$, saturated calomel reference electrode and platinum gauge counter electrode. Electrochemical measurements were carried out in a glovebox under $\mathrm{N}_{2}$ using an Autolab ${ }^{\circledR}$ /PGSTAT302N potentiostat. Ferrocene and $n-\mathrm{Bu}_{4} \mathrm{NPF}_{6}$ were purchased commercially and used as supplied.

\section{Preparation of additives}

\section{Benzaldehyde (21)}

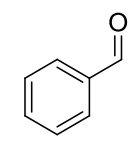

Prepared according to a literature procedure. ${ }^{[1]}$ To a solution of toluene $(1.25 \mathrm{~g}, 12.5 \mathrm{mmol})$ in $3.5 \mathrm{M}$ $\mathrm{HNO}_{3}(25 \mathrm{~mL})$ was added $\mathrm{Ce}\left(\mathrm{NH}_{4}\right)_{2}\left(\mathrm{NO}_{3}\right)_{6}(27.4 \mathrm{~g}, 50 \mathrm{mmol})$ in $3.5 \mathrm{M} \mathrm{HNO}_{3}(100 \mathrm{~mL})$. The reaction was heated at $80{ }^{\circ} \mathrm{C}$ for $2.5 \mathrm{~h}$ (the orange solution turned yellow in colour at $80{ }^{\circ} \mathrm{C}$ ), then cooled to rt. The crude product was extracted with $\mathrm{CHCl}_{3}(3 \times 50 \mathrm{~mL})$ and the combined organics washed with water until $\mathrm{pH}=7$. The organic layer was dried $\left(\mathrm{Na}_{2} \mathrm{SO}_{4}\right)$, filtered and concentrated in vacuo. Purification by distillation gave benzaldehyde- $\mathrm{h}_{6} 21$ as a pale yellow oil $(275 \mathrm{mg}, 18 \%) ;{ }^{1} \mathrm{H}$ NMR (400 $\left.\mathrm{MHz}, \mathrm{CDCl}_{3}\right) \delta 10.04(1 \mathrm{H}, \mathrm{s}, \mathrm{CHO}), 7.89(2 \mathrm{H}, \mathrm{dd}, J=8.3,1.3 \mathrm{~Hz}, \mathrm{ArH}), 7.65(1 \mathrm{H}, \mathrm{td}, \mathrm{J}=7.5,1.4 \mathrm{~Hz}$, $\operatorname{Ar} H), 7.55(2 \mathrm{H}, \mathrm{t}, J=7.5 \mathrm{~Hz}, \operatorname{Ar} H)$.

\section{Benzaldehyde- $d_{6}\left(21-d_{6}\right)$}

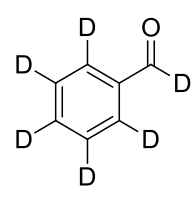

Toluene- $d_{8}$ was subjected to the procedure above to afford benzaldehyde- $d_{6} \mathbf{2 1 -} \mathbf{d}_{6}$ as a pale yellow oil (111 mg, 8\%); ${ }^{2} \mathrm{H}$ NMR (61 MHz, $\mathrm{CHCl}_{3}$ ) ठ 10.04 (1D, s, CDO), 7.91 (2D, s, $\operatorname{ArD}$ ), $7.66-7.56$ (3D, m, $\operatorname{ArD}) ;{ }^{13} \mathrm{C}$ NMR $\left(101 \mathrm{MHz}, \mathrm{CDCl}_{3}\right) \delta 192.1(\mathrm{t}, J=25.6 \mathrm{~Hz}, C D O), 136.2(C), 133.9(\mathrm{t}, J=24.9 \mathrm{~Hz}, C \mathrm{D})$, 129.3 (t, $J=24.9 \mathrm{~Hz}, C D), 128.5(\mathrm{t}, J=24.4 \mathrm{~Hz}, C D)$; HRMS $(+\mathrm{Cl}) \mathrm{m} / \mathrm{z}$ calculated for $\mathrm{C}_{7} \mathrm{H}_{1}{ }^{2} \mathrm{H}_{6} \mathrm{NO}$ $\left[\mathrm{M}+\mathrm{H}^{+}\right]$113.0868 Found 113.0870.

\section{2-(Pyridin-2-yl)propan-2-ol (31)}

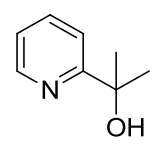

An oven-dried flask was charged with ethyl picolinate $(1.21 \mathrm{~g}, 8.0 \mathrm{mmol})$ and THF $(80 \mathrm{~mL})$. The flask was sealed inside a $\mathrm{N}_{2}$-filled glovebox and stirred at $0{ }^{\circ} \mathrm{C}$, before addition of $\mathrm{MeMgBr}\left(3.0 \mathrm{M} \mathrm{in} \mathrm{Et}_{2} \mathrm{O}\right.$ ) $(13.3 \mathrm{~mL}, 40.0 \mathrm{mmol})$ dropwise over $30 \mathrm{~min}$ at $0{ }^{\circ} \mathrm{C}$. The reaction was allowed to warm to rt, before 
careful addition of sat. $\mathrm{NH}_{4} \mathrm{Cl}(20 \mathrm{~mL})$ to quench. The mixture was poured into a separatory funnel with $\mathrm{Et}_{2} \mathrm{O}(30 \mathrm{~mL})$, the layers separated and aqueous layer extracted with $\mathrm{Et}_{2} \mathrm{O}(2 \times 30 \mathrm{~mL})$. The combined organic layers were dried $\left(\mathrm{Na}_{2} \mathrm{SO}_{4}\right)$, filtered and concentrated in vacuo to yield a yellow oil, which was purified by column chromatography $\left(5-12.5 \% \mathrm{Et}_{2} \mathrm{O} / \mathrm{Hexane}\left(1 \% \mathrm{Et}_{3} \mathrm{~N}\right)\right)$ to yield $\mathbf{3 1}$ as a light brown oil (278.0 mg, 25\%); IR $v_{\max }$ (neat) $3388(\mathrm{O}-\mathrm{H}), 2974$ - $2858(\mathrm{Ar}), 1591$ (Ar), 1570 (Ar), $1475,1462,1431,1369,1290,1275,1236 \mathrm{~cm}^{-1} ;{ }^{1} \mathrm{H}$ NMR $\left(400 \mathrm{MHz}, \mathrm{CDCl}_{3}\right) \delta 8.52(1 \mathrm{H}, \mathrm{d}, J=4.9 \mathrm{~Hz}$, $\operatorname{Ar} H), 7.70(1 \mathrm{H}, \mathrm{td}, J=7.7,1.8 \mathrm{~Hz}, \operatorname{ArH}), 7.39(1 \mathrm{H}, \mathrm{dt}, J=7.8,1.0 \mathrm{~Hz}, \operatorname{ArH}), 7.20(1 \mathrm{H}, \mathrm{ddd}, J=7.4$, 4.9, $1.1 \mathrm{~Hz}, \mathrm{ArH}), 5.06\left(1 \mathrm{H}\right.$, br. s, OH), $1.55\left(6 \mathrm{H}, \mathrm{s}, \mathrm{CH}_{3}\right) ;{ }^{13} \mathrm{C} \mathrm{NMR}\left(101 \mathrm{MHz}, \mathrm{CDCl}_{3}\right) \delta 166.0(\mathrm{C})$, $147.4(\mathrm{CH}), 136.9(\mathrm{CH}), 121.8(\mathrm{CH}), 118.7(\mathrm{CH}), 71.7(\mathrm{C}), 30.7\left(\mathrm{CH}_{3}\right)$; HRMS (+ESI) m/z calculated for $\mathrm{C}_{8} \mathrm{H}_{12} \mathrm{NO}\left[\mathrm{M}+\mathrm{H}^{+}\right]$138.0913 Found 138.0915. Data are consistent with literature. ${ }^{[2]}$

\section{2-Phenoxy-1-phenylethanol (47)}

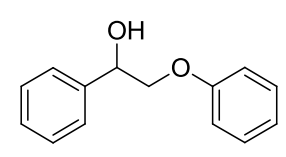

Prepared according to a literature procedure. ${ }^{[3]}$ An oven-dried flask was charged with 2-phenoxy-1phenylethanone (48) $(91.0 \mathrm{mg}, 0.42 \mathrm{mmol})$ and $6.5 \mathrm{~mL}$ ethanol was added. $\mathrm{NaBH}_{4}(19.5 \mathrm{mg}, 0.50$ $\mathrm{mmol}$ ) was added in one portion at rt. The flask was equipped with a reflux condenser and heated at reflux for $2 \mathrm{~h}$, before cooling to rt and pouring onto ice. Excess $\mathrm{NH}_{4} \mathrm{Cl}$ was added (until pH = $5-6$ ) and the reaction mixture stirred for $1 \mathrm{~h}$. The crude product was extracted with $\mathrm{Et}_{2} \mathrm{O}(3 \times 20 \mathrm{~mL})$, combined organics washed with brine $(30 \mathrm{~mL})$, dried $\left(\mathrm{Na}_{2} \mathrm{SO}_{4}\right)$, filtered and concentrated in vacuo loading onto celite. Column chromatography [Hexane : EtOAc (3:2)] gave 2-phenoxy-1-phenylethanol 47 as a white microcrystalline solid (70.0 mg, 78\%); m.p. $50-52{ }^{\circ} \mathrm{C}$ (lit. $48-50{ }^{\circ} \mathrm{C}^{[4]}$ ). IR $v_{\max }$ (neat) 3298 (br., O-H), 3059 - 2873 (C-H), 1597 (Ar), 1583 (Ar), 1496 (Ar), 1452, 1388, 1344, 1334, 1290, 1238, 1195, $1170,1151,1097,1078,1066,1043,1026 \mathrm{~cm}^{-1} ;{ }^{1} \mathrm{H}$ NMR $\left(400 \mathrm{MHz}, \mathrm{CDCl}_{3}\right) \delta 7.47(2 \mathrm{H}, \mathrm{d}, J=7.3 \mathrm{~Hz}$, $\operatorname{ArH}), 7.41(2 \mathrm{H}, \mathrm{t}, J=7.2 \mathrm{~Hz}, \operatorname{Ar} H), 7.38-7.28(3 \mathrm{H}, \mathrm{m}, \operatorname{ArH}), 6.99(1 \mathrm{H}, \mathrm{t}, J=7.3, \operatorname{ArH}), 6.95(2 \mathrm{H}, \mathrm{d}, \mathrm{J}=$ $8.1 \mathrm{~Hz}, \mathrm{ArH}), 5.14(1 \mathrm{H}, \mathrm{dd}, \mathrm{J}=8.8,3.3 \mathrm{~Hz}, \mathrm{CH}(\mathrm{OH}) \operatorname{Ar}), 4.16-4.11\left(1 \mathrm{H}, \mathrm{m}, \mathrm{CH}_{2}\right), 4.03(1 \mathrm{H}$, apt. t, J = $\left.9.2 \mathrm{~Hz}, \mathrm{CH}_{2}\right), 2.34\left(1 \mathrm{H}\right.$, br. s, OH); ${ }^{13} \mathrm{C}$ NMR $\left(101 \mathrm{MHz}, \mathrm{CDCl}_{3}\right) \delta 158.4(\mathrm{C}), 139.6(\mathrm{C}), 129.6(\mathrm{CH})$, 128.6 $(\mathrm{CH}), 128.2(\mathrm{CH}), 128.3(\mathrm{CH}), 121.3(\mathrm{CH}), 114.6(\mathrm{CH}), 73.3\left(\mathrm{CH}_{2}\right), 72.6(\mathrm{CH}) ; \mathrm{HRMS}(+\mathrm{Cl}) \mathrm{m} / \mathrm{z}$ calculated for $\mathrm{C}_{14} \mathrm{H}_{18} \mathrm{O}_{2} \mathrm{~N}\left[\mathrm{M}+\mathrm{NH}_{4}{ }^{+}\right]$232.1333; Found 232.1332. Data are consistent with the literature. ${ }^{[4]}$

\section{2-Phenoxy-1-phenylethanone (48)}

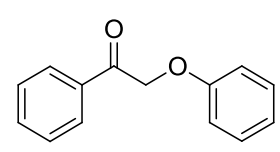

Prepared according to a literature procedure. ${ }^{[5]}$ An oven-dried flask was charged with $\mathrm{K}_{2} \mathrm{CO}_{3}(622 \mathrm{mg}$, $4.5 \mathrm{mmol}$ ), 2-bromoacetophenone (579 mg, $3.0 \mathrm{mmol})$, phenol (424 mg, $4.5 \mathrm{mmol}$ ) and DMF (10 mL) and stirred at rt under Ar for $24 \mathrm{~h}$. The reaction was quenched with water $(30 \mathrm{~mL})$ and extracted with 
$\mathrm{Et}_{2} \mathrm{O}(3 \times 30 \mathrm{~mL})$. Combined organics were dried $\left(\mathrm{Na}_{2} \mathrm{SO}_{4}\right)$, filtered and concentrated in vacuo to yield an off-white solid, which was recrystallised from $\mathrm{DCM} /$ Hexane to yield $\mathbf{4 8}$ as a white microcrystalline solid (133.0 mg, 21\%); m.p. $62-64{ }^{\circ} \mathrm{C}$ (lit. $60-61{ }^{\circ} \mathrm{C}^{[6]}$ ); IR $v_{\max }$ (neat) 3064 - 2800 (C-H), 1705 (C=O), 1597 (Ar), 1581 (Ar), 1498 (Ar), 1479, 1448, 1431, 1384, 1302, 1290, 1247, $1224 \mathrm{~cm}^{-1} ;{ }^{1} \mathrm{H}$ $\operatorname{NMR}\left(400 \mathrm{MHz}, \mathrm{CDCl}_{3}\right) \delta 8.02(2 \mathrm{H}, \mathrm{dd}, J=8.3,1.2 \mathrm{~Hz}, \operatorname{Ar} H), 7.63(1 \mathrm{H}, \mathrm{t}, J=7.4 \mathrm{~Hz}, \operatorname{ArH}), 7.51(2 \mathrm{H}$, apt. t, $J=7.8 \mathrm{~Hz}, \operatorname{Ar} H), 7.30(2 \mathrm{H}, \mathrm{dd}, J=8.8,1.3 \mathrm{~Hz}, \operatorname{ArH}), 7.00(1 \mathrm{H}, \mathrm{t}, J=7.3 \mathrm{~Hz}, \operatorname{Ar} H), 6.97(2 \mathrm{H}$, dd, $\left.J=8.8,0.9 \mathrm{~Hz}, \mathrm{ArH}), 5.28\left(2 \mathrm{H}, \mathrm{s}, \mathrm{CH}_{2}\right) ;{ }^{13} \mathrm{C} \mathrm{NMR}\left(101 \mathrm{MHz}^{\mathrm{CDCl}}\right)_{3}\right) 194.6(C=\mathrm{O}), 15(C), 134.6(C)$, $133.8(\mathrm{CH}), 129.6(\mathrm{CH}), 128.8(\mathrm{CH}), 128.2(\mathrm{CH}), 121.7(\mathrm{CH}), 114.8(\mathrm{CH}), 70.9\left(\mathrm{CH}_{2}\right)$ HRMS (+ESI) $\mathrm{m} / \mathrm{z}$ calculated for $\mathrm{C}_{14} \mathrm{H}_{13} \mathrm{O}_{2}\left[\mathrm{M}+\mathrm{H}^{+}\right]$213.0910; Found 213.0909. Data are consistent with the literature. ${ }^{[4]}$

\section{TRANSESTERIFICATION OF ETHYL BENZOATE WITH POTASSIUM tert-BUTOXIDE}

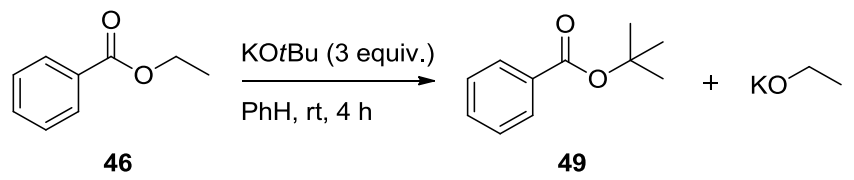

To an oven-dried pressure tube was added ethyl benzoate 46 (75.1 mg, $0.5 \mathrm{mmol})$. KOtBu (168 mg, $1.5 \mathrm{mmol}$ ) and benzene $(5 \mathrm{~mL})$ were added. The tube was sealed in a glovebox and stirred at $\mathrm{rt}$ for 4 h. A $1 \mathrm{~mL}$ sample of the cloudy white slurry was quenched with water $(50 \mathrm{~mL})$ and extracted with $\mathrm{Et}_{2} \mathrm{O}$ $(3 \times 50 \mathrm{~mL})$. The combined organic layers were dried $\left(\mathrm{Na}_{2} \mathrm{SO}_{4}\right)$, filtered through a plug of silica gel and concentrated in vacuo to yield 49 as a colourless oil $\left(8.0 \mathrm{mg}, 11 \%\right.$ ); IR $v_{\max }$ (neat) 2976 - 2931 (CH), 1710 (C=O), 1594 (Ar), 1450, 1367, 1313, 1288, 1253, 1165, 1112, 1068, $1026 \mathrm{~cm}^{-1} ;{ }^{1} \mathrm{H}$ NMR $\left(400 \mathrm{MHz}, \mathrm{CDCl}_{3}\right) \delta 7.99(2 \mathrm{H}, \mathrm{d}, J=8.6 \mathrm{~Hz}, \operatorname{ArH}), 7.39(1 \mathrm{H}, \mathrm{t}, J=7.5, \operatorname{ArH}), 7.28(2 \mathrm{H}, \mathrm{t}, J=7.6 \mathrm{~Hz}$, $\mathrm{ArH}), 1.61\left(9 \mathrm{H}, \mathrm{s}, \mathrm{CH}_{3}\right) ;{ }^{13} \mathrm{C}$ NMR $\left(101 \mathrm{MHz}, \mathrm{CDCl}_{3}\right) \delta 165.8(\mathrm{C}), 132.4(\mathrm{CH}), 132.0(\mathrm{C}), 129.4(\mathrm{CH})$, $128.2(\mathrm{CH}), 81.0(\mathrm{C}), 28.2\left(\mathrm{CH}_{3}\right)$;

Data are consistent with the literature. ${ }^{[7]}$

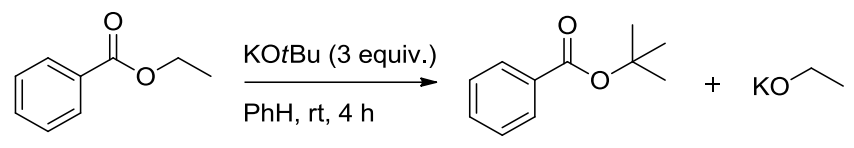

46

49 
${ }^{1} \mathrm{H}$ NMR (400 MHz, $\mathrm{CDCl}_{3}$ ) - Crude product (49)
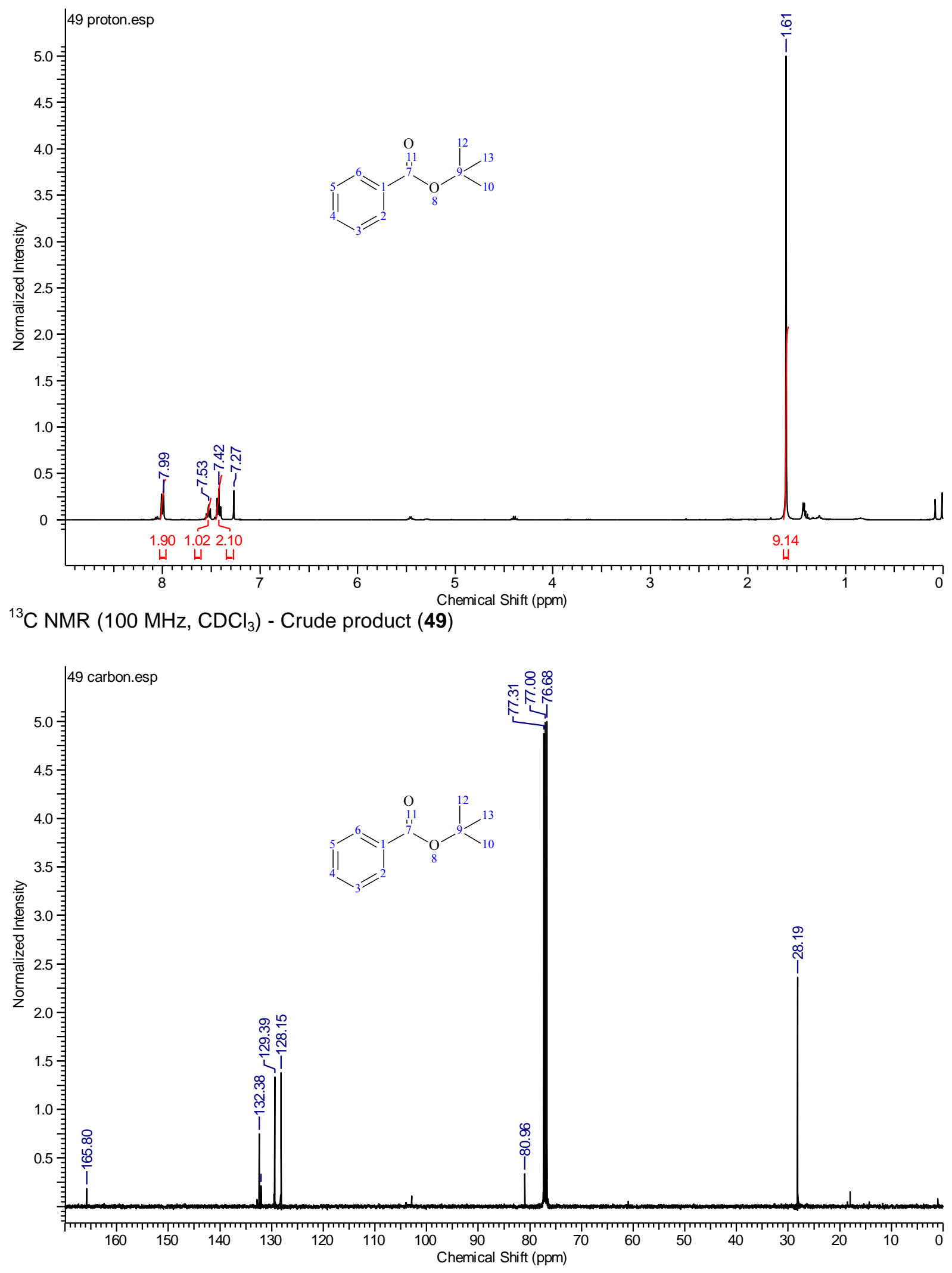

SF 


\section{KOtBu-MEDIATED BENZYLIC DEUTERATION OF 2-PYRIDINECARBINOL IN THE PRESENCE OF $\mathrm{D}_{2} \mathrm{O}$}

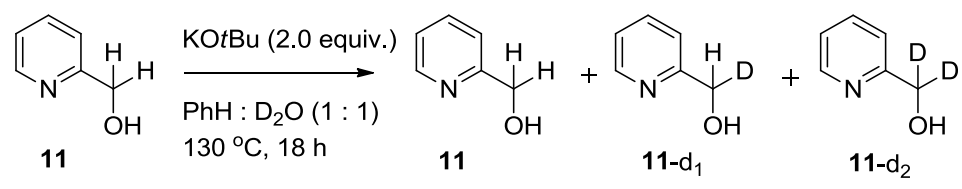

A pressure tube was charged with 2-pyridinecarbinol $11(55.0 \mathrm{mg}, 0.5 \mathrm{mmol})$ and $\mathrm{KO}$ tBu $(112.0 \mathrm{mg}$, $1.0 \mathrm{mmol})$. Benzene $(2.5 \mathrm{~mL})$ and $\mathrm{D}_{2} \mathrm{O}(2.5 \mathrm{~mL})$ were added. The reaction was sealed, removed from the glovebox and heated at $130{ }^{\circ} \mathrm{C}$ for $18 \mathrm{~h}$. The reaction was quenched with $\mathrm{H}_{2} \mathrm{O}(50 \mathrm{~mL})$ and $\mathrm{DCM}$ $(30 \mathrm{~mL})$ was added. The layers were separated and aqueous extracted with DCM $(2 \times 30 \mathrm{~mL})$, combined organics dried $\left(\mathrm{Na}_{2} \mathrm{SO}_{4}\right)$, filtered and concentrated in vacuo to yield the crude product which was analysed by ${ }^{1} \mathrm{H},{ }^{2} \mathrm{H}$ and ${ }^{13} \mathrm{C}$ NMR.

${ }^{1} \mathrm{H}$ NMR $\left(400 \mathrm{MHz}, \mathrm{CDCl}_{3}\right)$ - Crude product $\left(\mathbf{1 1}, \mathbf{1 1}-\mathrm{d}_{1}\right.$ and $\left.\mathbf{1 1}-\mathrm{d}_{2}\right) . \mathrm{D}_{2} \mathrm{O}$ used in the reaction.

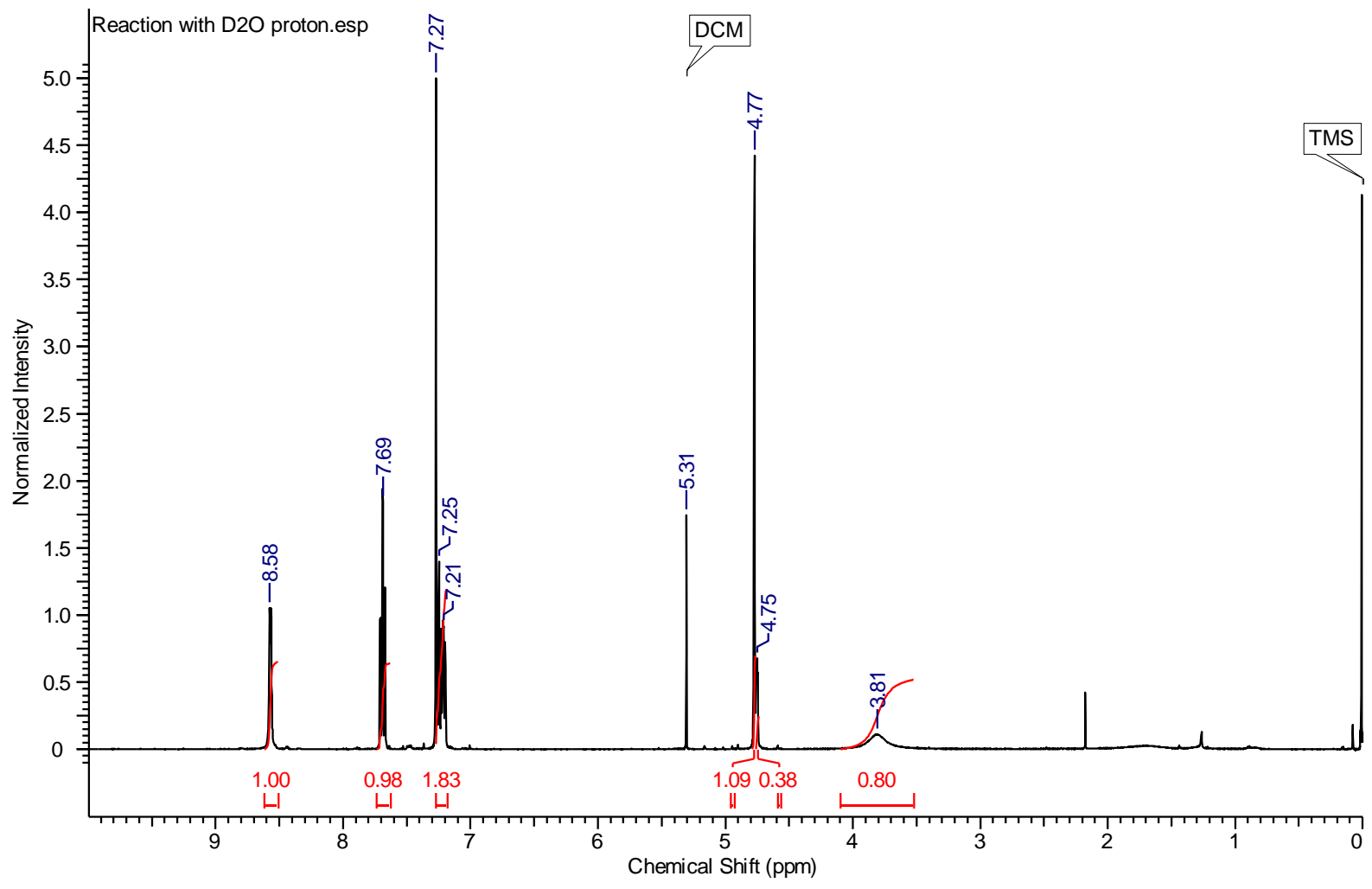


${ }^{1} \mathrm{H}$ NMR $\left(400 \mathrm{MHz}, \mathrm{CDCl}_{3}\right.$ ) - Crude product (11). $\mathrm{H}_{2} \mathrm{O}$ used in the reaction for comparison.

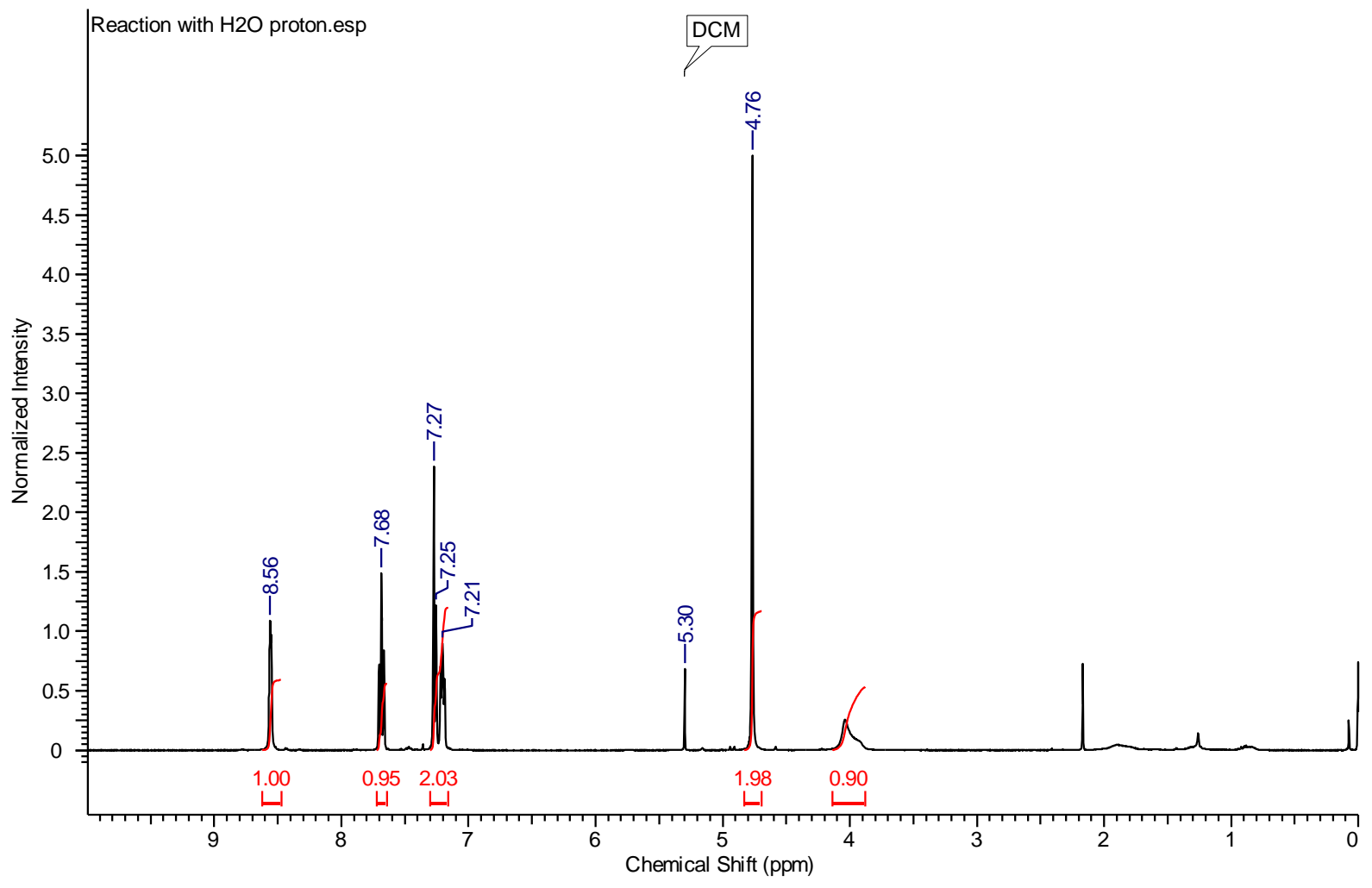

${ }^{2} \mathrm{H}$ NMR $\left(61 \mathrm{MHz}, \mathrm{CHCl}_{3}\right)$ - Crude product $\left(\mathbf{1 1}, \mathbf{1 1}-\mathrm{d}_{1}\right.$ and $\left.11-\mathrm{d}_{2}\right) . \mathrm{D}_{2} \mathrm{O}$ used in the reaction.

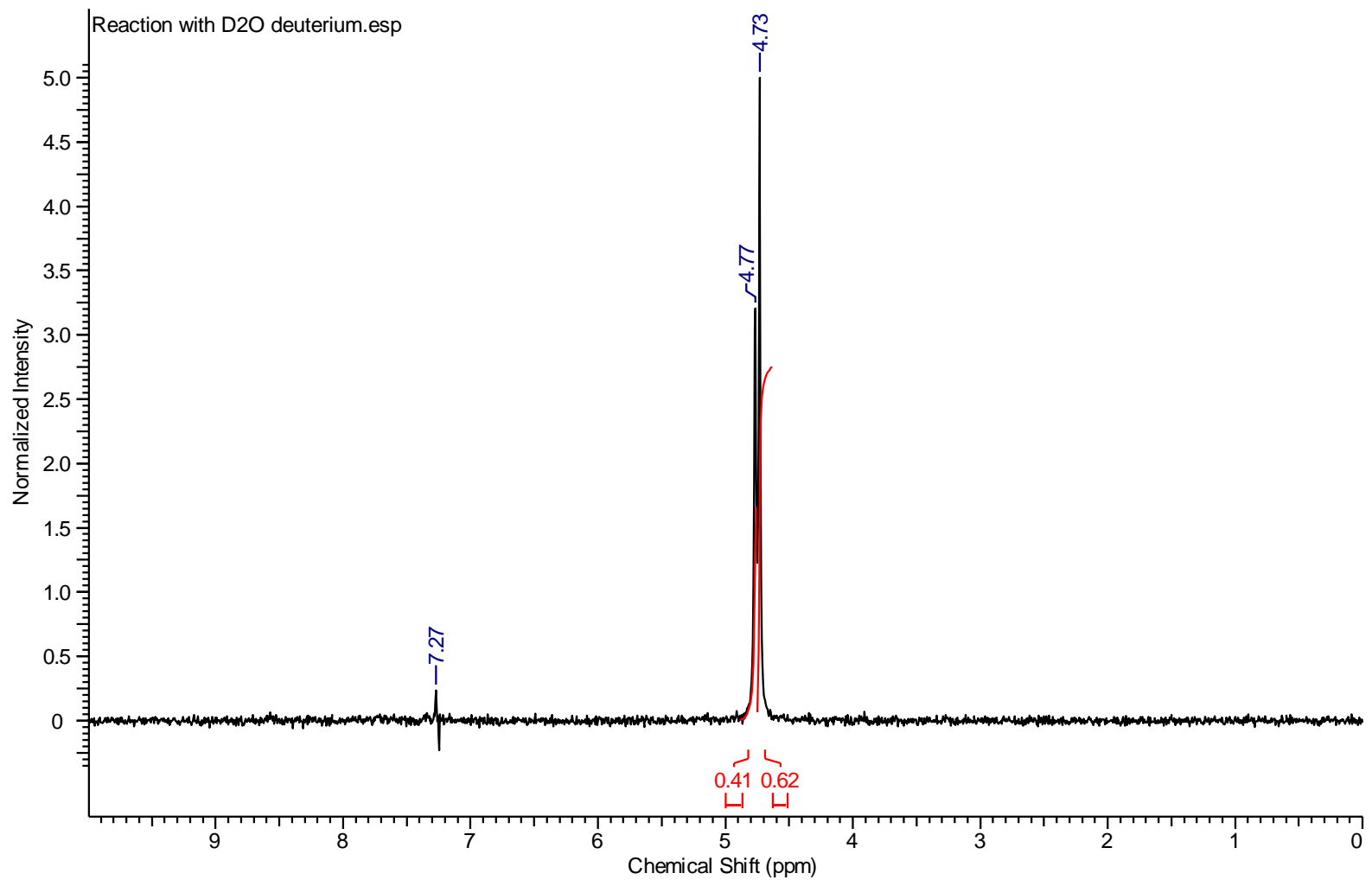


${ }^{13} \mathrm{C}$ NMR $\left(100 \mathrm{MHz}, \mathrm{CDCl}_{3}\right)$ - Crude product $\left(\mathbf{1 1}, \mathbf{1 1}-\mathrm{d}_{1}\right.$ and $\left.11-\mathrm{d}_{2}\right) . \mathrm{D}_{2} \mathrm{O}$ used in the reaction.

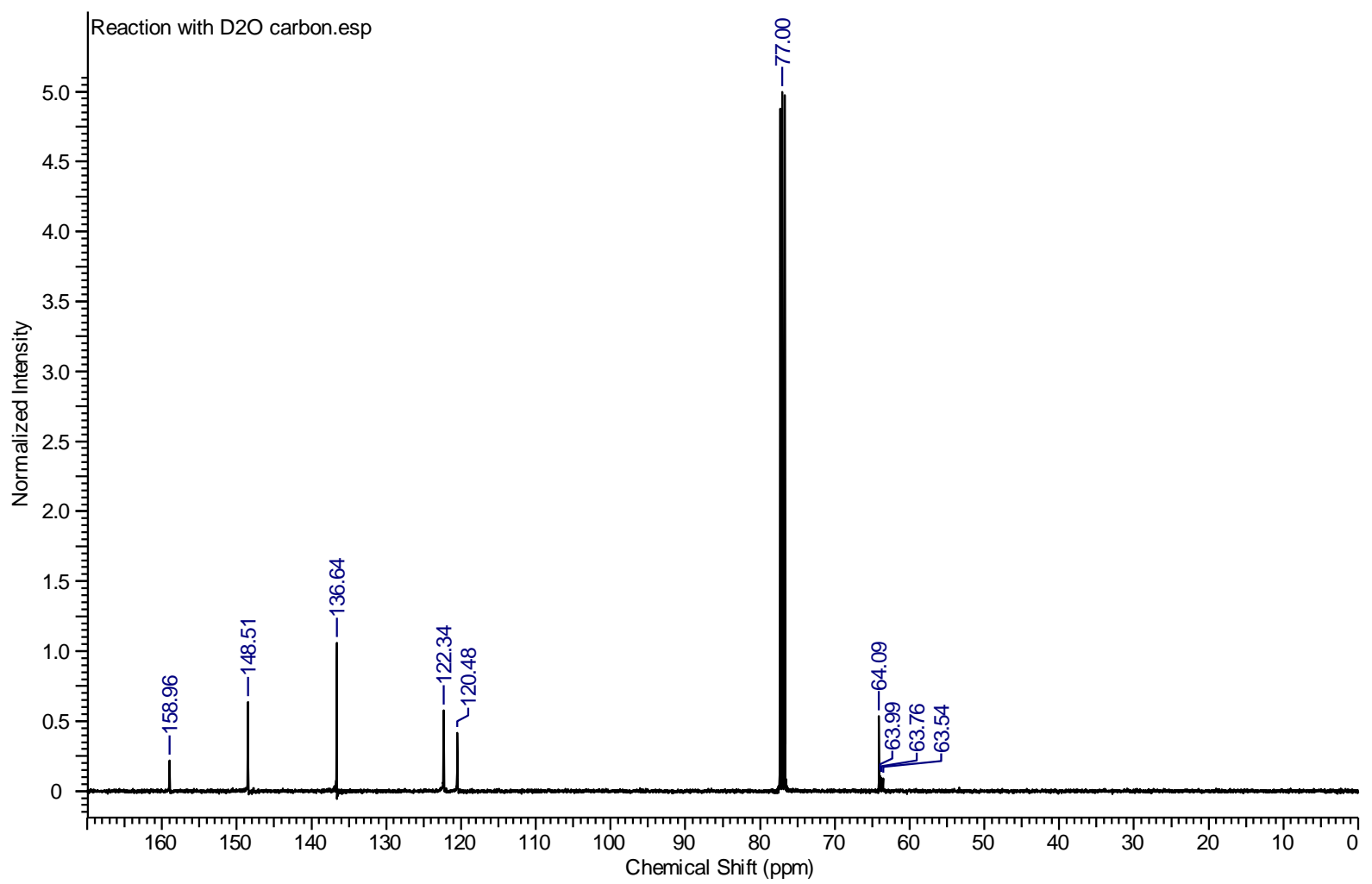

${ }^{13} \mathrm{C}$ NMR $\left(100 \mathrm{MHz}, \mathrm{CDCl}_{3}\right)($ Zoom $)$ - Crude product $\left(\mathbf{1 1}, \mathbf{1 1}-\mathrm{d}_{1}\right.$ and $\left.11-\mathrm{d}_{2}\right) . \mathrm{D}_{2} \mathrm{O}$ used in the reaction.

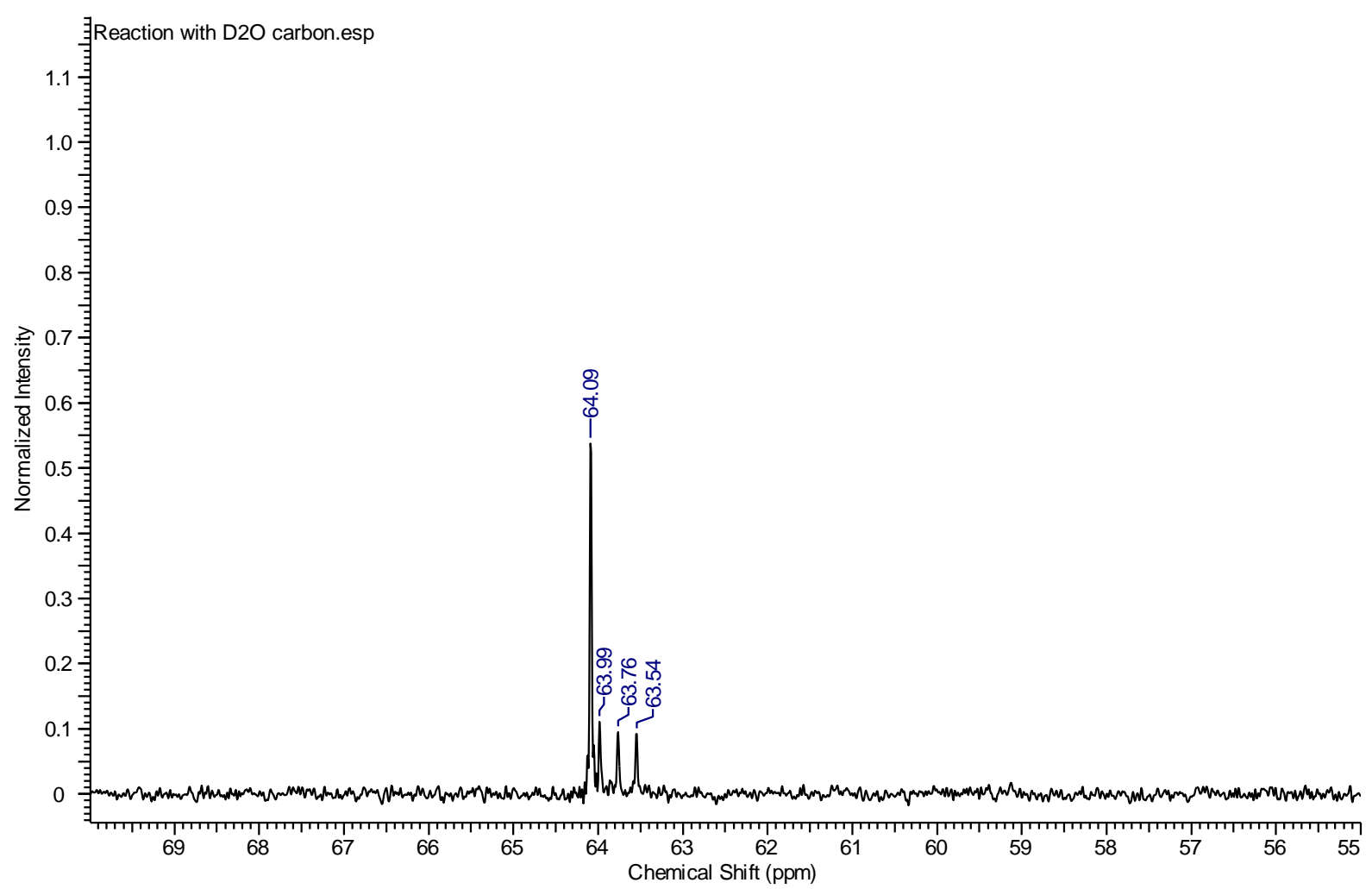




\section{COUPLING OF 4-BROMOTOLUENE UNDER LITERATURE CONDITIONS}

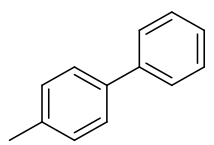

Prepared according to a literature procedure. ${ }^{[8]}$ To an oven-dry pressure tube was added 4bromotoluene 9, $\mathrm{R}=p$-Me $(0.5 \mathrm{mmol})$ and 2-pyridinecarbinol 11 (0.05 mmol). KOtBu (112 mg, 1.0 $\mathrm{mmol}$ ) and benzene $(5 \mathrm{~mL})$ were added. The tube was sealed in a glovebox and heated at $80{ }^{\circ} \mathrm{C}$ for $24 \mathrm{~h}$. After cooling to $\mathrm{rt}$, the reaction was quenched with water $(50 \mathrm{~mL})$ and extracted with $\mathrm{Et}_{2} \mathrm{O}(3 \mathrm{x}$ $50 \mathrm{~mL})$. The combined organic layers were dried $\left(\mathrm{Na}_{2} \mathrm{SO}_{4}\right)$, filtered and concentrated in vacuo. Purification by column chromatography (hexane) afforded 4-methyl-1,1'-biphenyl (10, $\mathrm{R}=p$-Me) as a white microcrystalline solid (50.3 mg, 60\%); m.p. $46-48{ }^{\circ} \mathrm{C}$ (lit. ${ }^{[9]} 46-48{ }^{\circ} \mathrm{C}$ ); IR $v_{\max }$ (neat) 2958 $2852(\mathrm{C}-\mathrm{H}), 1458(\mathrm{Ar}), 1377 \mathrm{~cm}^{-1} ;{ }^{1} \mathrm{H}$ NMR $\left(400 \mathrm{MHz}, \mathrm{CDCl}_{3}\right) \delta 7.60(2 \mathrm{H}, \mathrm{dd}, J=8.3,1.3 \mathrm{~Hz}, \mathrm{ArH})$, $7.52(2 \mathrm{H}, \mathrm{d}, J=8.3 \mathrm{~Hz}, \operatorname{ArH}), 7.44(2 \mathrm{H}, \mathrm{t}, J=7.5 \mathrm{~Hz}, \operatorname{ArH}), 7.34(1 \mathrm{H}, \mathrm{t}, J=7.4, \operatorname{ArH}), 7.26(2 \mathrm{H}, \mathrm{d}, J=$ $8.0 \mathrm{~Hz}, \mathrm{ArH}), 2.41\left(3 \mathrm{H}, \mathrm{s}, \mathrm{CH}_{3}\right) ;{ }^{13} \mathrm{C} \mathrm{NMR}\left(101 \mathrm{MHz}, \mathrm{CDCl}_{3}\right)^{*} \delta 141.2(C), 138.4(C), 137.0(C), 129.5$ $(\mathrm{CH}), 128.7(\mathrm{CH}), 127.1(\mathrm{CH}), 127.0(\mathrm{CH}), 21.1\left(\mathrm{CH}_{3}\right)$;

Data are consistent with the literature. ${ }^{[10]}{ }^{*}$ The remaining $\mathrm{CH}$ could not be observed, consistent with the listed data in the literature. ${ }^{10}$

\section{GeNERAL PROCEDURES FOR COUPLING REACTIONS OF 2,6-DIMETHYLHALOBENZENES}

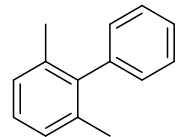

13

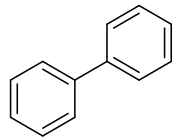

14

To an oven-dried pressure tube was added 2,6-dimethylhalobenzene $(0.5 \mathrm{mmol})$ and 'initiator' $(0.05$ mmol). KOt-Bu (168 mg, $1.5 \mathrm{mmol}$ ) and benzene $(5 \mathrm{~mL})$ were added. The tube was sealed in a glovebox and heated at $150{ }^{\circ} \mathrm{C}$ for $21 \mathrm{~h}$. After cooling to rt, the reaction was quenched with water (50 $\mathrm{mL})$ and extracted with $\mathrm{Et}_{2} \mathrm{O}(3 \times 50 \mathrm{~mL})$. The combined organic layers were dried $\left(\mathrm{Na}_{2} \mathrm{SO}_{4}\right)$, filtered and concentrated in vacuo. Purification by column chromatography (Hexane) afforded an inseparable mixture of biphenyl and 2,6-dimethyl-1,1'-biphenyl (always in a $3: 1$ molar ratio by ${ }^{1} \mathrm{H}$ NMR) as a white microcrystalline solid; biphenyl 14: ${ }^{1} \mathrm{H}$ NMR $\left(400 \mathrm{MHz}, \mathrm{CDCl}_{3}\right) \delta 7.64-7.59(4 \mathrm{H}, \mathrm{m}, \mathrm{ArH}), 7.46$ (4H, apt t., $J=7.5 \mathrm{~Hz}, \operatorname{Ar} H), 7.38$ - $7.34(2 \mathrm{H}, \mathrm{m}, \operatorname{ArH})$; 2,6-dimethyl-1,1'-biphenyl 13: ${ }^{1} \mathrm{H}$ NMR (400 $\left.\mathrm{MHz}, \mathrm{CDCl}_{3}\right) \delta 7.19-7.10(5 \mathrm{H}, \mathrm{m}, \mathrm{ArH}), 7.34-7.50(3 \mathrm{H}, \mathrm{m}, \mathrm{ArH})$, (partially obscured by biphenyl peaks) $2.05\left(6 \mathrm{H}, \mathrm{s}, \mathrm{CH}_{3}\right)$. 
${ }^{1} \mathrm{H}$ NMR (400 MHz, $\mathrm{CHCl}_{3}$ ) - purified biaryls 13 and 14

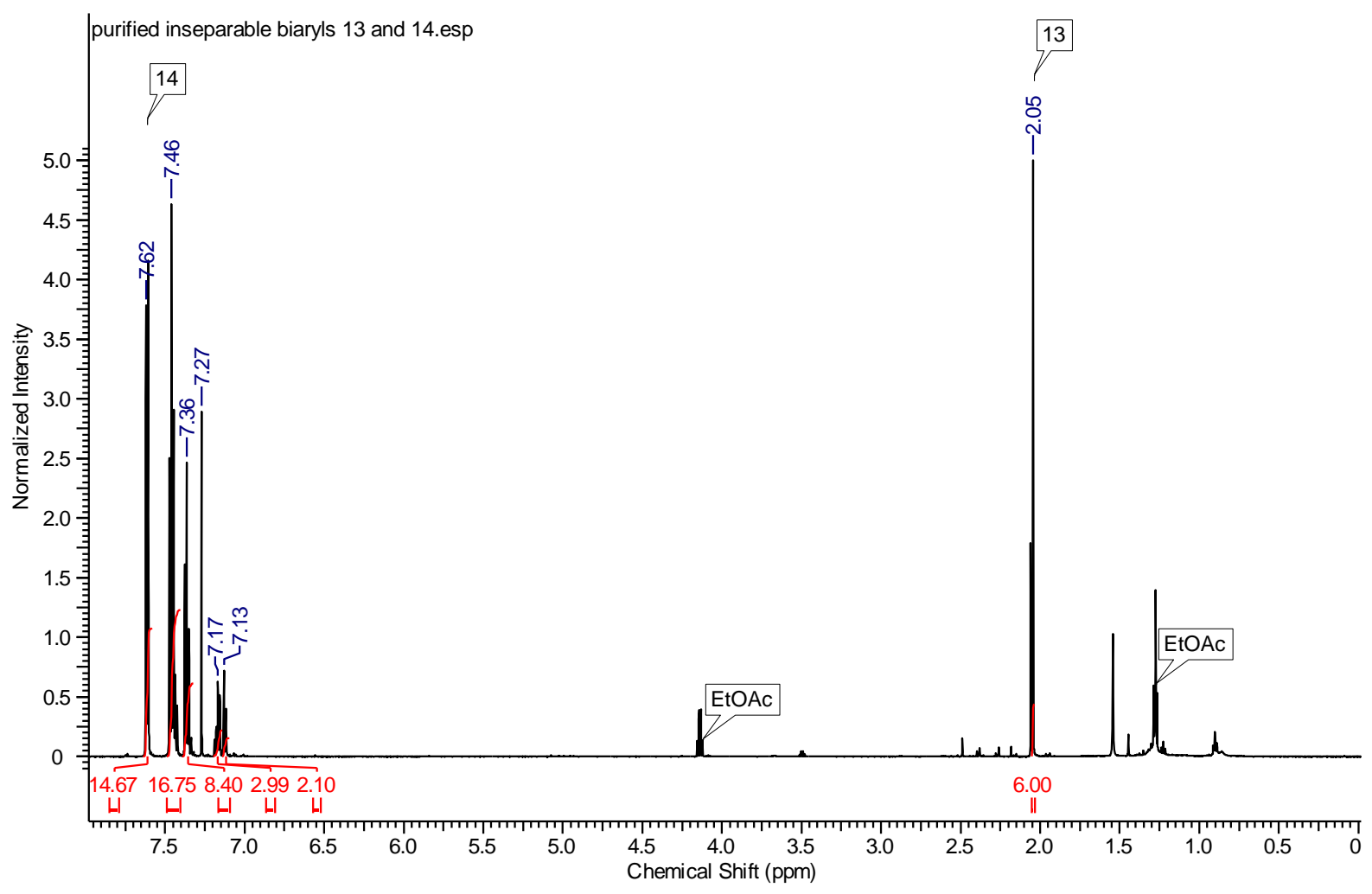

${ }^{1} \mathrm{H}$ NMR data are consistent with the literature. ${ }^{[11]}$ Alternatively, 1,3,5-trimethoxybenzene $(8.4 \mathrm{mg}, 0.05$ mmol) was added to the crude reaction mixture, the residue dissolved in $\mathrm{CDCl}_{3}$ and combined yield of biaryls determined by ${ }^{1} \mathrm{H}$ NMR.

Alternative procedure for coupling reactions run under 'milder conditions': To an oven-dry pressure tube was added 2,6-dimethylhalobenzene $12(0.5 \mathrm{mmol})$ and 'initiator' $(0.05 \mathrm{mmol})$. KO $t$-Bu $(112 \mathrm{mg}, 1.0 \mathrm{mmol})$ and benzene $(5 \mathrm{~mL})$ were added. The tube was sealed in a glovebox and heated at $130{ }^{\circ} \mathrm{C}$ for $18 \mathrm{~h}$. Work up and purification was conducted in the same way as the previous general procedure outlined. 
7. Representative ${ }^{1} \mathrm{H}$ NMR Spectra from coupling Reactions of 2,6DIMETHYLIODOBENZENE
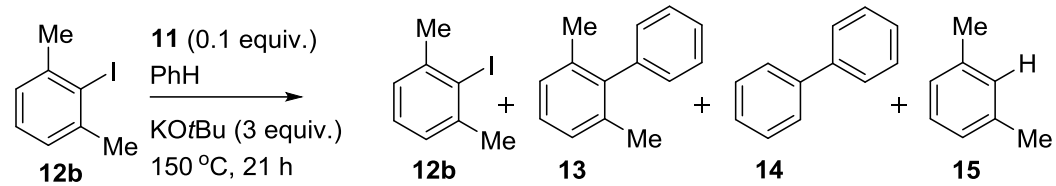

${ }^{1} \mathrm{H}$ NMR (400 MHz, $\mathrm{CHCl}_{3}$ ) - 2-pyridinecarbinol (11) as an additive.
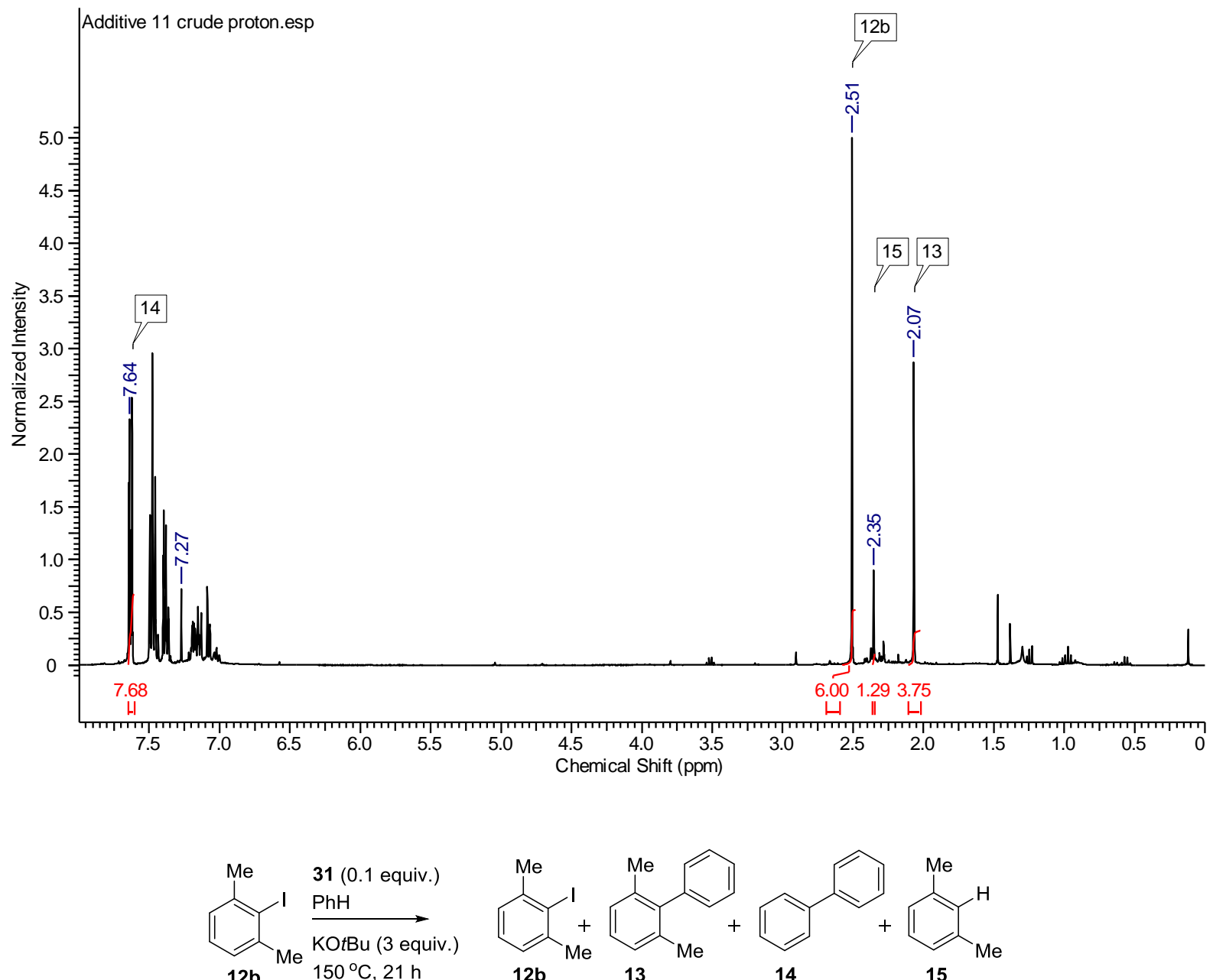

${ }^{1} \mathrm{H}$ NMR (400 MHz, $\mathrm{CHCl}_{3}$ ) - 2-(pyridin-2-yl)propan-2-ol (31) as an additive. 


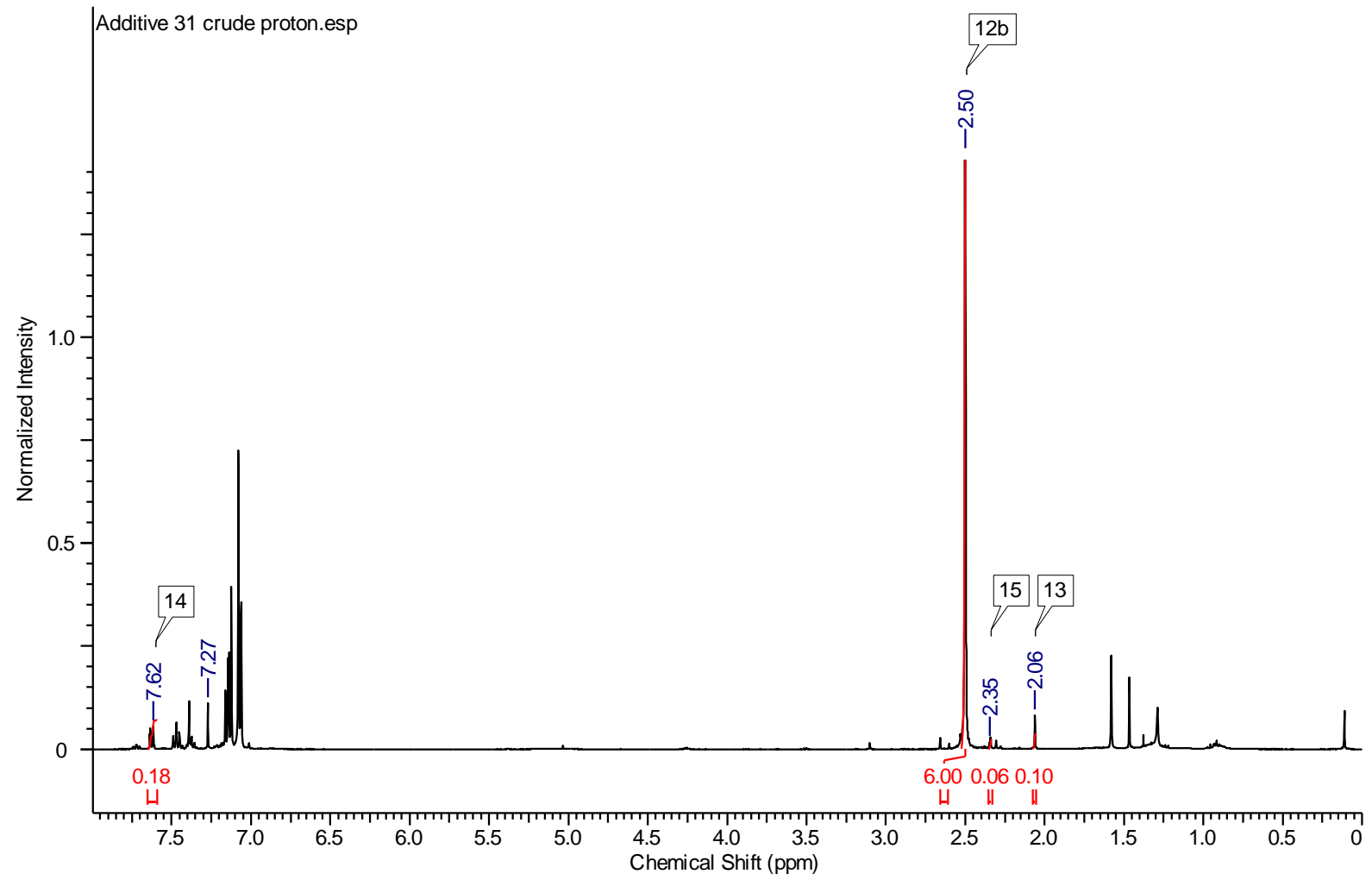




\section{8. ${ }^{1} \mathrm{H}$ NMR SPECTRAL COMPARISON OF PIVALOPHENONE AND ACETOPHENONE}

Commercially available pivalophenone and acetophenone were analysed by ${ }^{1} \mathrm{H}$ NMR and I.R. spectroscopy. The aromatic protons ortho- to the ketone are significantly more shielded for pivalophenone than acetophenone by ${ }^{1} \mathrm{H}$ NMR, which can indicate deviation from co-planarity for the carbonyl group and the arene. Furthermore, pivalophenone has a lower $\mathrm{C}=\mathrm{O}$ stretching frequency than acetophone by I.R.

${ }^{1} \mathrm{H}$ NMR - pivalophenone (left) and acetophenone (right):
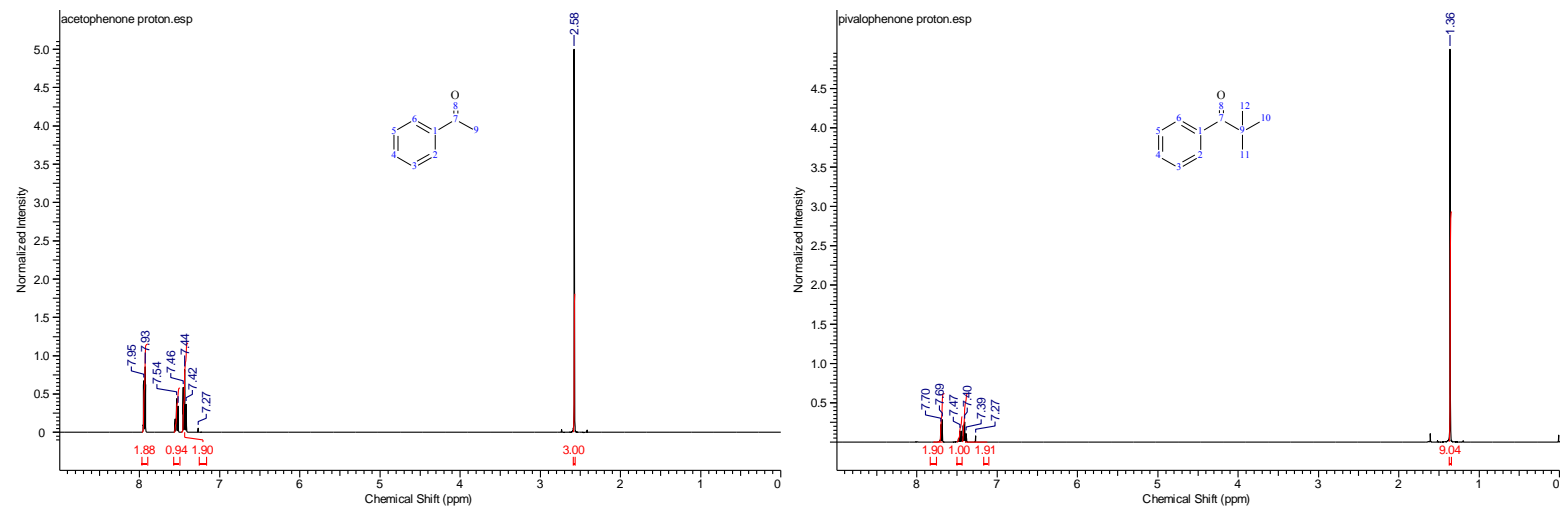

\begin{tabular}{lccc}
\hline Ketone $^{\mathrm{a}}$ & $\delta\left[\mathrm{H}_{\text {ortho }}(\mathrm{ppm})\right.$ & $\delta\left[\mathrm{H}_{\text {meta }}\right](\mathrm{ppm})$ & $\delta\left[\mathrm{H}_{\text {para }}(\mathrm{ppm})\right.$ \\
\hline pivalophenone $^{\mathrm{b}}$ & $7.71-7.68$ & $7.42-7.38$ & $7.48-7.44$ \\
pivalophenone $^{[12]}$ & $7.70-7.67$ & $7.45-7.35$ & $7.45-7.35$ \\
acetophenone $^{\mathrm{b}}$ & $7.96-7.93$ & $7.46-7.42$ & $7.56-7.52$ \\
acetophenone $^{[13]}$ & 7.97 & $7.49-7.45$ & 7.57 \\
\hline${ }^{2}{ }^{2}$ etoph
\end{tabular}

${ }^{a}$ References to the literature. ${ }^{b}$ This study.

\section{COUPLING OF 4-CHLOROTOLUENE UNDER LITERATURE CONDITIONS}

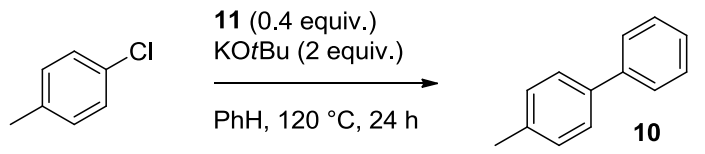

According to a modified literature procedure. ${ }^{[8]}$ To an oven-dried pressure tube was added 4chlorotoluene (116.0 mg, $1.0 \mathrm{mmol})$ and 2-pyridinemethanol 11 (43.7 mg, $0.40 \mathrm{mmol})$. KOt-Bu (224.4 $\mathrm{mg}, 2.0 \mathrm{mmol})$ and benzene $(8 \mathrm{~mL})$ were added. The tube was sealed in a glovebox and heated at $120^{\circ} \mathrm{C}$ for $24 \mathrm{~h}$. After cooling to $\mathrm{rt}$, the reaction was quenched with water $(10 \mathrm{~mL})$ and extracted with $\mathrm{Et}_{2} \mathrm{O}(3 \times 20 \mathrm{~mL})$. The combined organic layers were dried $\left(\mathrm{Na}_{2} \mathrm{SO}_{4}\right)$, filtered and concentrated in vacuo. $1,3,5$-Trimethoxybenzene $(16.8 \mathrm{mg}, 0.10 \mathrm{mmol}$ ) was added to the crude reaction mixture (as an internal standard for NMR calibration), the residue dissolved in $\mathrm{CDCl}_{3}$ and yield of $\mathbf{1 0}$ determined as $7.0 \%$ by ${ }^{1} \mathrm{H}$ NMR. This is consistent with the literature which reports an $8 \%$ yield of $\mathbf{1 0}$ (determined by calibrated GC methods) under identical conditions. ${ }^{\left[{ }^{[3}\right.}$

This reaction was conducted side-by-side with a blank reaction (carried out as above, but without additive 11) which gave no detectable coupled product. 
Alternatively, a reaction carried out at $80^{\circ} \mathrm{C}$ for $24 \mathrm{~h}$ (using the above conditions, but with 0.1 equiv. of additive 11) gave only a trace amount of coupled product.

\section{SYNTHESIS OF (5-METHOXYPYRIDIN-2-YL)METHANOL FOR USE AS AN ADDITIVE IN COUPLINGS OF CHLOROARENES}

METHYL 5-METHOXYPYRIDINE-2-CARBOXYLATE (51)

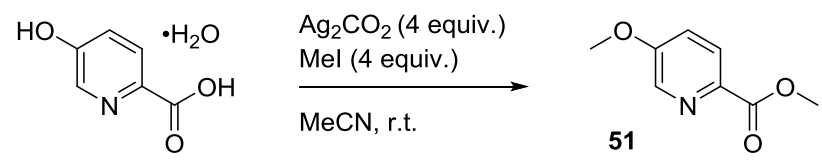

lodomethane $(2.71 \mathrm{~g}, 1.19 \mathrm{~mL}, 19.1 \mathrm{mmol}$ ) was added to a suspension of 5-hydroxypyridine monohydrate $(750.0 \mathrm{mg}, 4.8 \mathrm{mmol}), \mathrm{Ag}_{2} \mathrm{CO}_{3}(5.27 \mathrm{~g}, 19.1 \mathrm{mmol})$ and $\mathrm{MeCN}(23 \mathrm{~mL})$. The mixture was stirred at room temperature for $64 \mathrm{~h}$ before the solids were filtered and washed with EtOAc $(3 \mathrm{x}$ $20 \mathrm{~mL}$ ). The filtrate was concentrated under reduced pressure to give the crude material. Purification by column chromatography (EtOAc) gave 51 as a yellow solid $\left(482.0 \mathrm{mg}, 60 \%\right.$ ); m.p. $64-66{ }^{\circ} \mathrm{C}$ (lit. 69-72 $\left.{ }^{\circ} \mathrm{C}^{[14]}\right) ;{ }^{1} \mathrm{H}$ NMR $\left(400 \mathrm{MHz}, \mathrm{CDCl}_{3}\right) \delta 8.40(1 \mathrm{H}, \mathrm{dd}, J=3.0,0.5 \mathrm{~Hz}, \mathrm{ArH}), 8.12(1 \mathrm{H}, \mathrm{dd}, J=8.6$, $0.5 \mathrm{~Hz}, \mathrm{ArH}), 7.27(1 \mathrm{H}, \mathrm{dd}, 8.6,3.0 \mathrm{~Hz}, \mathrm{ArH}), 3.99(3 \mathrm{H}, \mathrm{s}), 3.93(3 \mathrm{H}, \mathrm{s}) ;{ }^{13} \mathrm{C} \mathrm{NMR}\left(101 \mathrm{MHz}, \mathrm{CDCl}_{3}\right) \delta$ $165.4(\mathrm{C}), 158.1(\mathrm{C}), 140.2(\mathrm{C}), 138.1(\mathrm{CH}), 126.4(\mathrm{CH}), 119.6(\mathrm{CH}), 55.7\left(\mathrm{CH}_{3}\right), 42.5\left(\mathrm{CH}_{3}\right)$; Data are consistent with the literature. ${ }^{[15]}$

\section{(5-methoxypyridin-2-yl)methanol (49)}

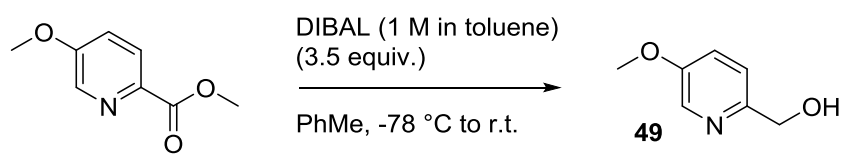

Methyl 5-methoxypyridine-2-carboxylate $50(250.0 \mathrm{mg}, 1.5 \mathrm{mmol})$ was added to an oven-dried flask under argon and dissolved in anhydrous toluene $(14.9 \mathrm{~mL})$. The solution was cooled to $-78^{\circ} \mathrm{C}$, DIBAL (1 $\mathrm{M}$ in toluene) (5.2 $\mathrm{mL}, 5.2 \mathrm{mmol}$ ) was added dropwise by syringe, and the reaction was stirred at 0 ${ }^{\circ} \mathrm{C}$ for $1.5 \mathrm{~h}$. The reaction was then quenched with sat. aq. potassium sodium tartrate $(20 \mathrm{~mL})$ and stirred at room temperature for $1 \mathrm{~h}$. The mixture was extracted with EtOAc ( $3 \times 20 \mathrm{~mL})$, combined organic phases dried $\left(\mathrm{Na}_{2} \mathrm{SO}_{4}\right)$, filtered, and concentrated in vacuo. Purification by column chromatography (EtOAc) gave $\mathbf{4 9}$ as a pale yellow oil, which solidified on standing to a pale yellow solid (126.0 mg, 61\%); m.p. 46-48 ${ }^{\circ} \mathrm{C}$; IR $v_{\max }$ (neat) 3140 - 2837 (C-H), 1580 (Ar), 1489 (Ar), 1292 $\mathrm{cm}^{-1} ;{ }^{1} \mathrm{H}$ NMR $\left(400 \mathrm{MHz}, \mathrm{CDCl}_{3}\right) \delta 8.25(1 \mathrm{H}, \mathrm{dd}, J=2.7,0.9 \mathrm{~Hz}, \operatorname{ArH}), 7.23(1 \mathrm{H}, \mathrm{dd}, J=8.5,2.7 \mathrm{~Hz}$, $\operatorname{ArH}), 7.19(1 \mathrm{H}, \mathrm{dd}, J=8.5,0.9 \mathrm{~Hz}, \operatorname{ArH}), 4.71(2 \mathrm{H}, \mathrm{s}), 3.87(3 \mathrm{H}, \mathrm{s}), 3.45(1 \mathrm{H}, \mathrm{br} . \mathrm{s}, \mathrm{OH}) ;{ }^{13} \mathrm{C} N M R$ $\left(101 \mathrm{MHz}, \mathrm{CDCl}_{3}\right) \delta 154.9(\mathrm{C}), 151.5(\mathrm{C}), 135.8(\mathrm{CH}), 121.7(\mathrm{CH}), 121.1(\mathrm{CH}), 64.1\left(\mathrm{CH}_{2}\right), 55.7$ $\left(\mathrm{CH}_{3}\right)$; Data are consistent with the literature. ${ }^{[16][17]}$ 


\section{COUPLING OF 4-CHLOROTOLUENE USING (5-METHOXYPYRIDIN-2-YL)METHANOL AS AN ADDITIVE}

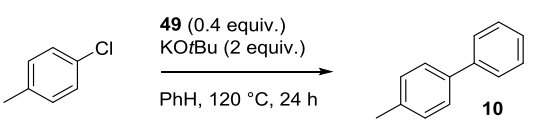

According to a modified literature procedure. ${ }^{[8]}$ To an oven-dried pressure tube was added 4chlorotoluene (116.0 mg, $1.0 \mathrm{mmol}$ ) and (5-methoxypyridin-2-yl)methanol 49 (55.7 mg, $0.4 \mathrm{mmol})$. $\mathrm{KO}$-Bu $(224.4 \mathrm{mg}, 2.0 \mathrm{mmol})$ and benzene $(8 \mathrm{~mL})$ were added. The tube was sealed in a glovebox and heated at $120{ }^{\circ} \mathrm{C}$ for $24 \mathrm{~h}$. After cooling to rt, the reaction was quenched with water $(10 \mathrm{~mL})$ and extracted with $\mathrm{Et}_{2} \mathrm{O}(3 \times 20 \mathrm{~mL})$. The combined organic layers were dried $\left(\mathrm{Na}_{2} \mathrm{SO}_{4}\right)$, filtered and concentrated in vacuo. $1,3,5$-Trimethoxybenzene $(16.8 \mathrm{mg}, 0.10 \mathrm{mmol})$ was added to the crude reaction mixture, the residue dissolved in $\mathrm{CDCl}_{3}$ and yield of 10 determined as $0.3 \%$ by ${ }^{1} \mathrm{H}$ NMR.

This reaction was conducted side-by-side with a blank reaction (carried out as above, but without (5methoxypyridin-2-yl)methanol 49) which gave no detectable coupled product.

\section{Cyclic Voltammetry}

All solutions were prepared at $10 \mathrm{mM}$ concentration (in $0.1 \mathrm{M} \mathrm{Bu}_{4} \mathrm{NPF}_{6} / \mathrm{DMF}$ ) using ferrocene as an external standard to ensure consistency throughout the study and whose peak height (ca. $4.7 \times 10^{-6}$ A) corresponds to a 1-electron oxidation. Dry, degassed DMF was used throughout; the study conducted within a glovebox under $\mathrm{N}_{2}$ with $0.1 \mathrm{M} \mathrm{Bu}_{4} \mathrm{NPF}_{6} / \mathrm{DMF}$ as the electrolyte. Potentials are given relative to the saturated calomel electrode (vs. SCE). Data for ferrocene are consistent with the literature. ${ }^{[18]}$

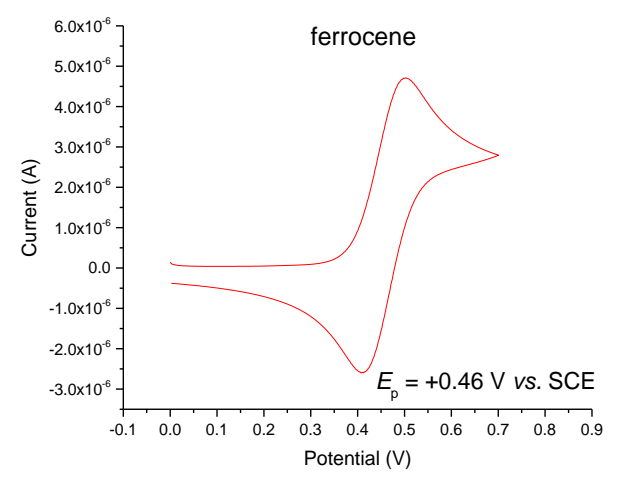



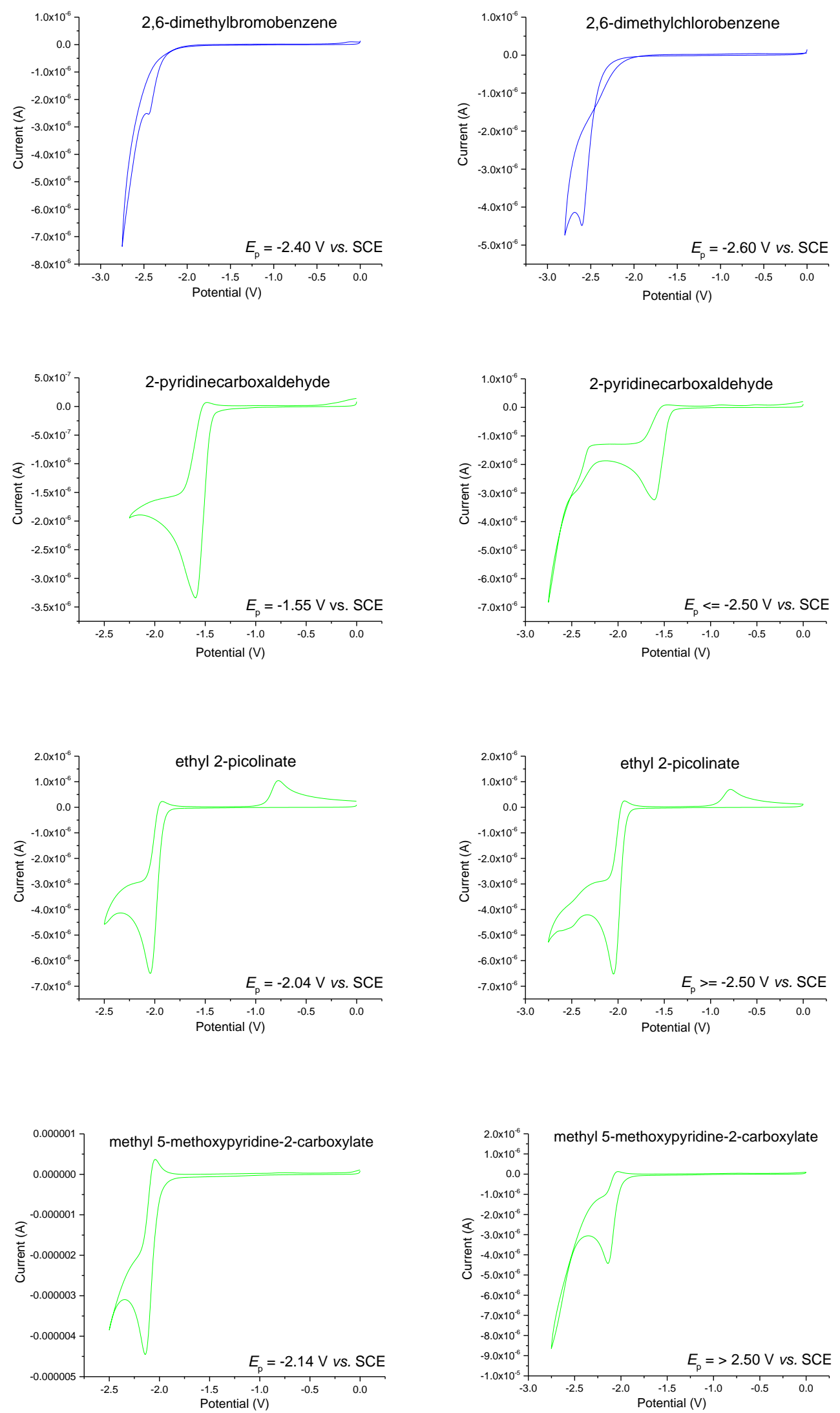


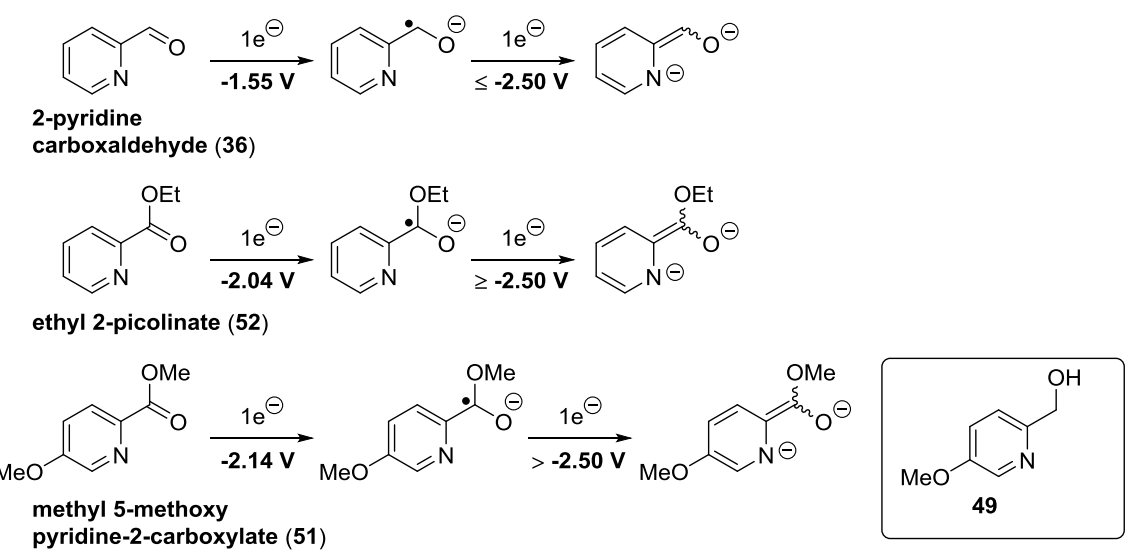

The CV for 2,6-dimethylchlorobenzene $12 \mathrm{a}$ and 2,6-dimethylchlorobenzene $12 \mathrm{c}$, at a scan rate of 50 $\mathrm{mV} \mathrm{s}{ }^{-1}$, each show (by comparison with ferrocene) a single-electron reduction peak at -2.40 and $-2.60 \mathrm{~V}$, respectively. These potentials are consistent with literature values for chlorobenzene and bromobenzene $\left(-2.40 \mathrm{~V}\right.$ vs. SCE) ${ }^{[19]}$ The resulting radical anions must have some lifetime (if fragmentation to the aryl radical had occurred, a two-electron reduction would have been expected, since aryl radicals are easier to reduce than haloarenes). ${ }^{[20]}$ The CV for 2-pyridinecarboxaldehyde (36), ethyl 2-picolinate and methyl 5-methoxypyridine-2-carboxylate (51), at a scan rate of $50 \mathrm{mV} \mathrm{s}^{-1}$, each show single-electron reduction peaks at $-1.55,-2.04$ and $-2.14 \mathrm{~V}$, respectively. The cathodicanodic peak separation for each of these reductions, $\Delta E_{p-p}$ obtained was $100 \mathrm{mV}$ (close to the value obtained for ferrocene at the same scan rate $(90 \mathrm{mV} c f .59 \mathrm{mV} / \mathrm{n}$ for an ideal one-electron transfer), indicating a high degree of reversibility (and so rapid kinetics) for the electron transfer processes.

In the case of 2-pyridinecarboxaldehyde (36), a second event is visible at a potential $\leq-2.50 \mathrm{~V} v s$. SCE. For ethyl 2-picolinate the second event is more visible and an oxidation peak can be observed at a potential $\geq-2.50 \mathrm{~V} v$ s. SCE. For methyl 5-methoxypyridine-2-carboxylate (51) the event is no longer visible and likely occurs at a potential more negative than $-2.50 \mathrm{~V} v s$. SCE. This suggests feasible thermodynamics for the reduction of bromo- and chloroarenes $\left(E_{\mathrm{p}}=-2.40 \mathrm{~V}\right.$ and $-2.60 \mathrm{~V} v \mathrm{~s}$. SCE, respectively) with these pyridinecarbinol-derived dianions and that the dianion derived from methyl 5-methoxypyridine-2-carboxylate $(\mathbf{5 0})$ appears to be more reducing than 2pyridinecarboxaldehyde (36). However, in reactions of chloroarenes 2-pyridinecarbinol (11) appears to be a more effective (although ineffective in general) additive than (5-methoxypyridin-2-yl)methanol (49). This is rationalised by the additional alkoxy-substituent serving to deactivate benzylic deprotonation by releasing electrons into the aromatic ring. 


\section{3. ${ }^{1} \mathrm{H}$ NMR AND ${ }^{13} \mathrm{C}$ NMR SPECTRA OF KEY COMPOUNDS}

${ }^{1} \mathrm{H}$ NMR $\left(400 \mathrm{MHz}, \mathrm{CDCl}_{3}\right)-\mathbf{3 1}$

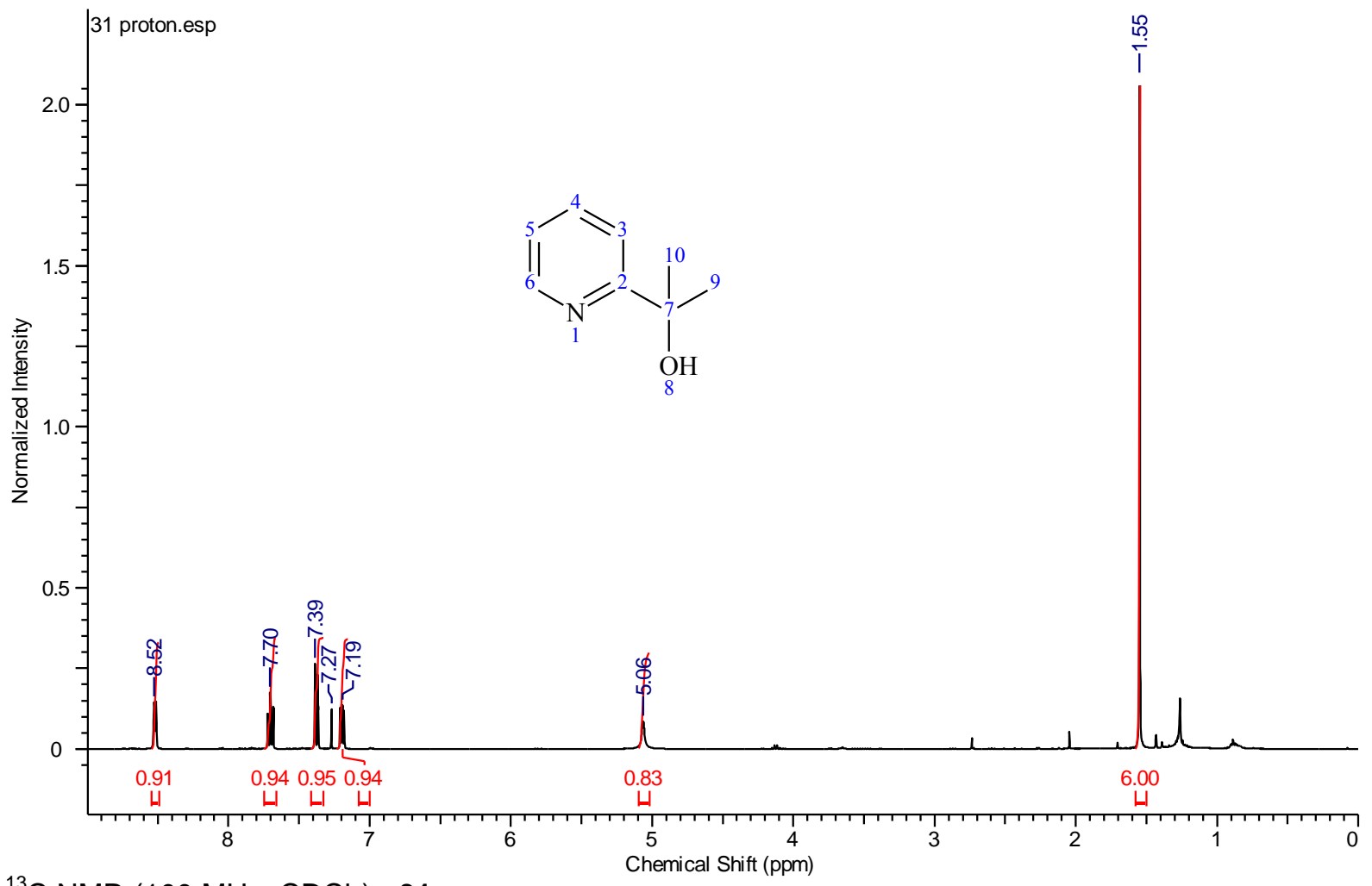

${ }^{13} \mathrm{C} \mathrm{NMR}\left(100 \mathrm{MHz}, \mathrm{CDCl}_{3}\right)-\mathbf{3 1}$

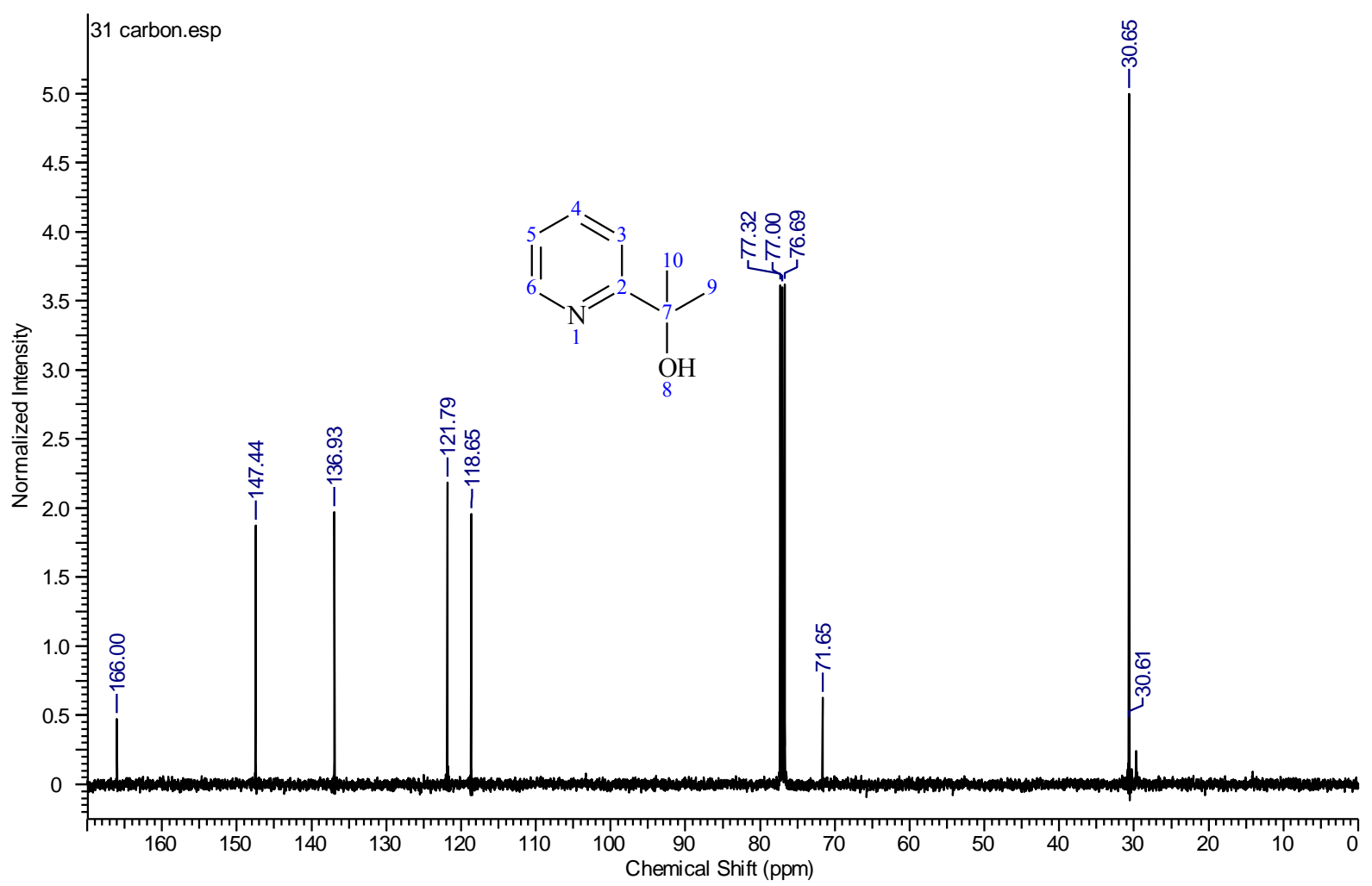


${ }^{1} \mathrm{H}$ NMR $\left(400 \mathrm{MHz}, \mathrm{CDCl}_{3}\right)-\mathbf{2 1}-\mathbf{h}_{\mathbf{6}}$

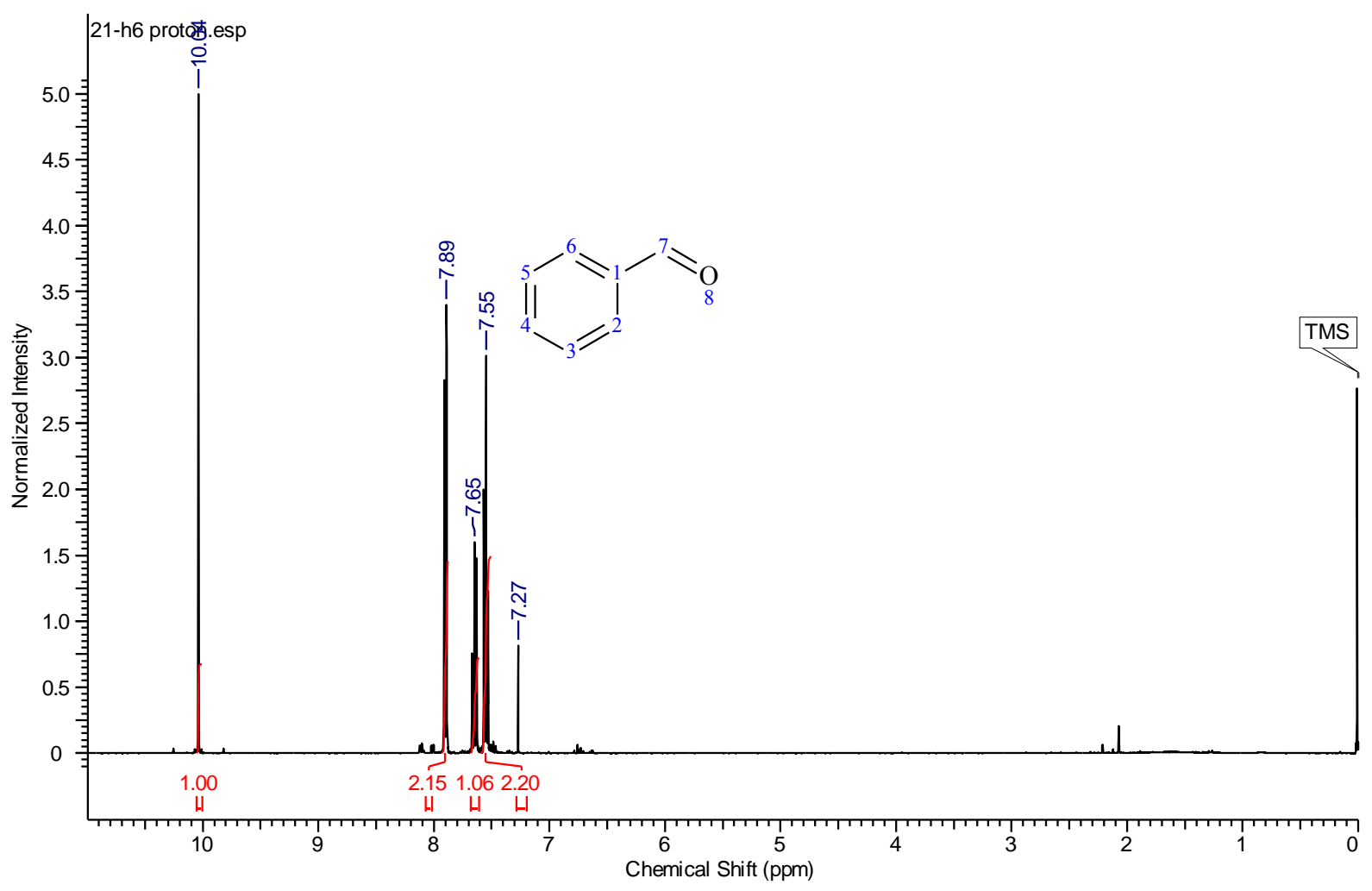

${ }^{2} \mathrm{H}$ NMR $\left(61 \mathrm{MHz}, \mathrm{CHCl}_{3}\right)-\mathbf{2 1 - \mathbf { d } _ { 6 }}$

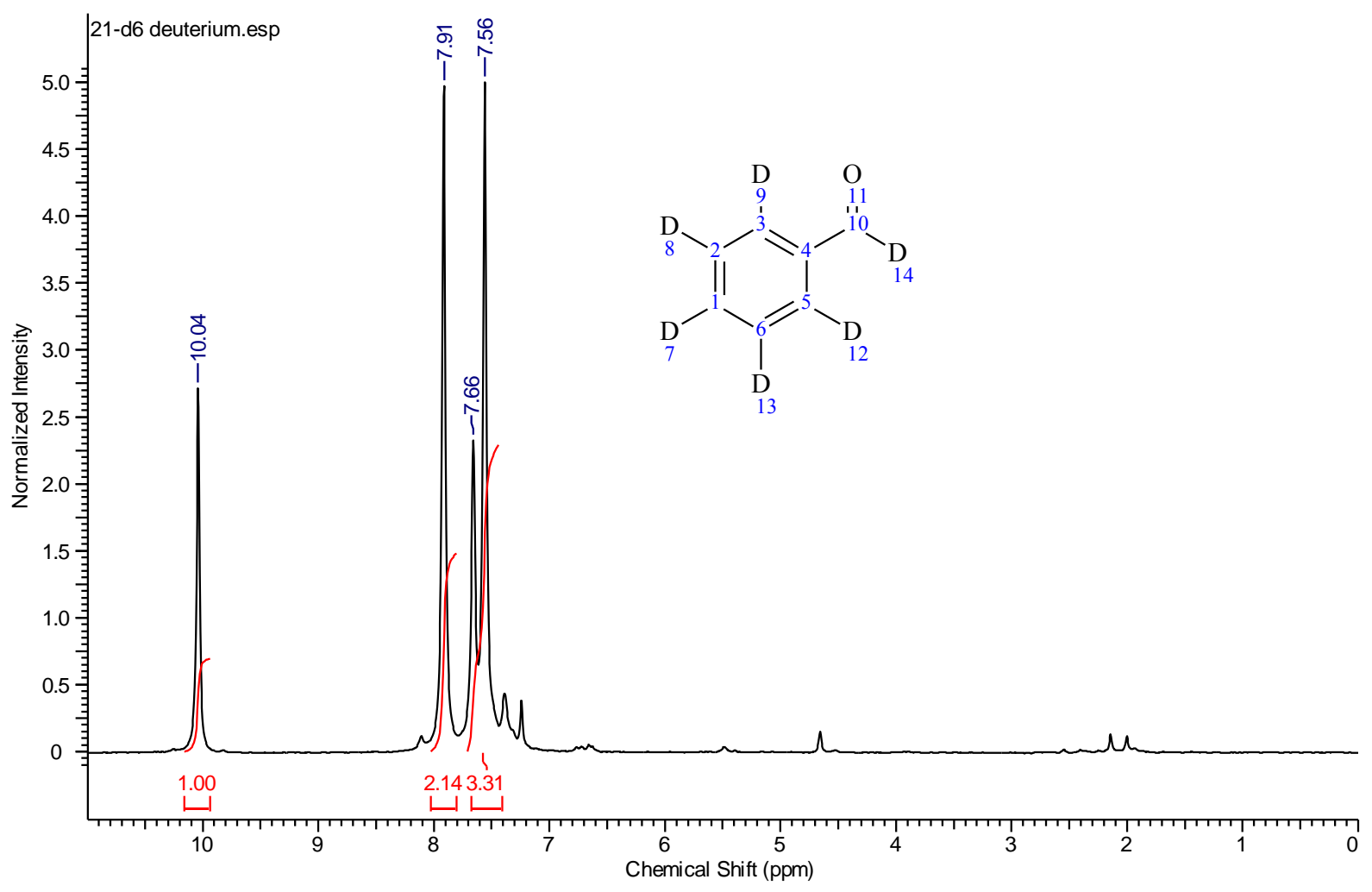


${ }^{13} \mathrm{C} \mathrm{NMR}\left(100 \mathrm{MHz}, \mathrm{CDCl}_{3}\right)-\mathbf{2 1 - \mathbf { d } _ { 6 }}$

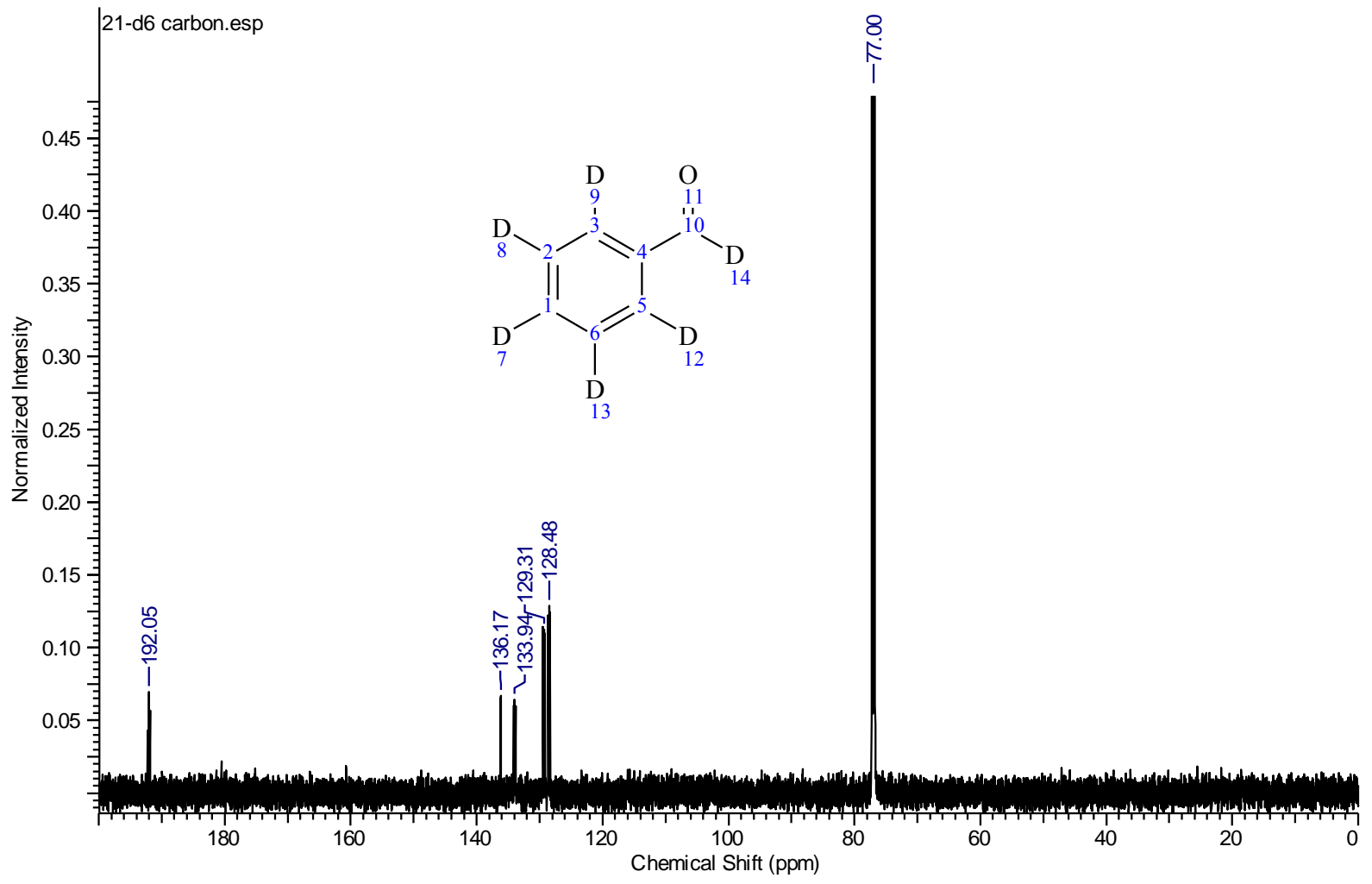

${ }^{13} \mathrm{C}$ NMR $\left(100 \mathrm{MHz}, \mathrm{CDCl}_{3}\right)(\mathrm{Zoom})-\mathbf{2 1 - \mathbf { d } _ { 6 }}$

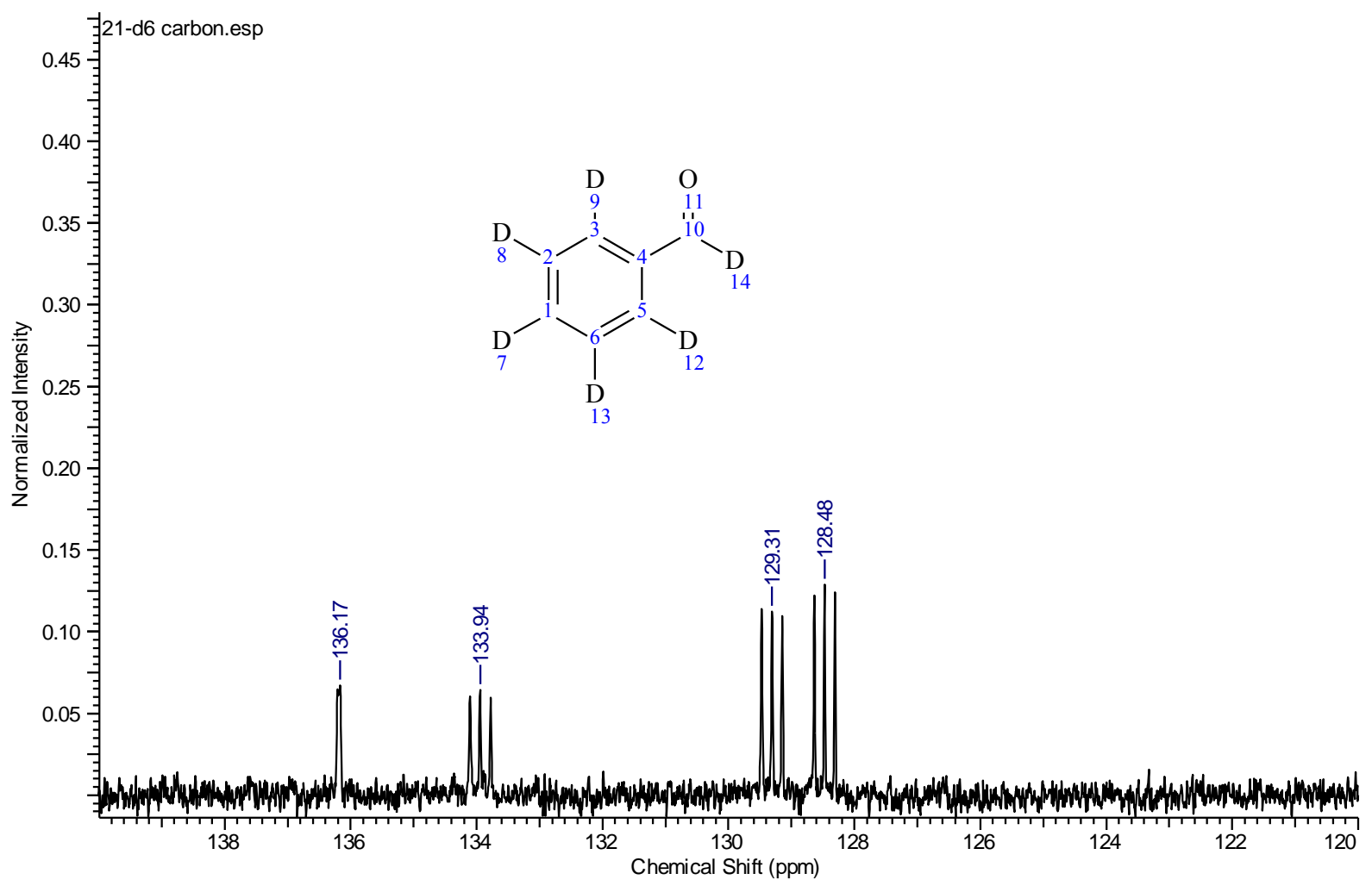


${ }^{1} \mathrm{H}$ NMR (400 MHz, $\left.\mathrm{CDCl}_{3}\right)-47$

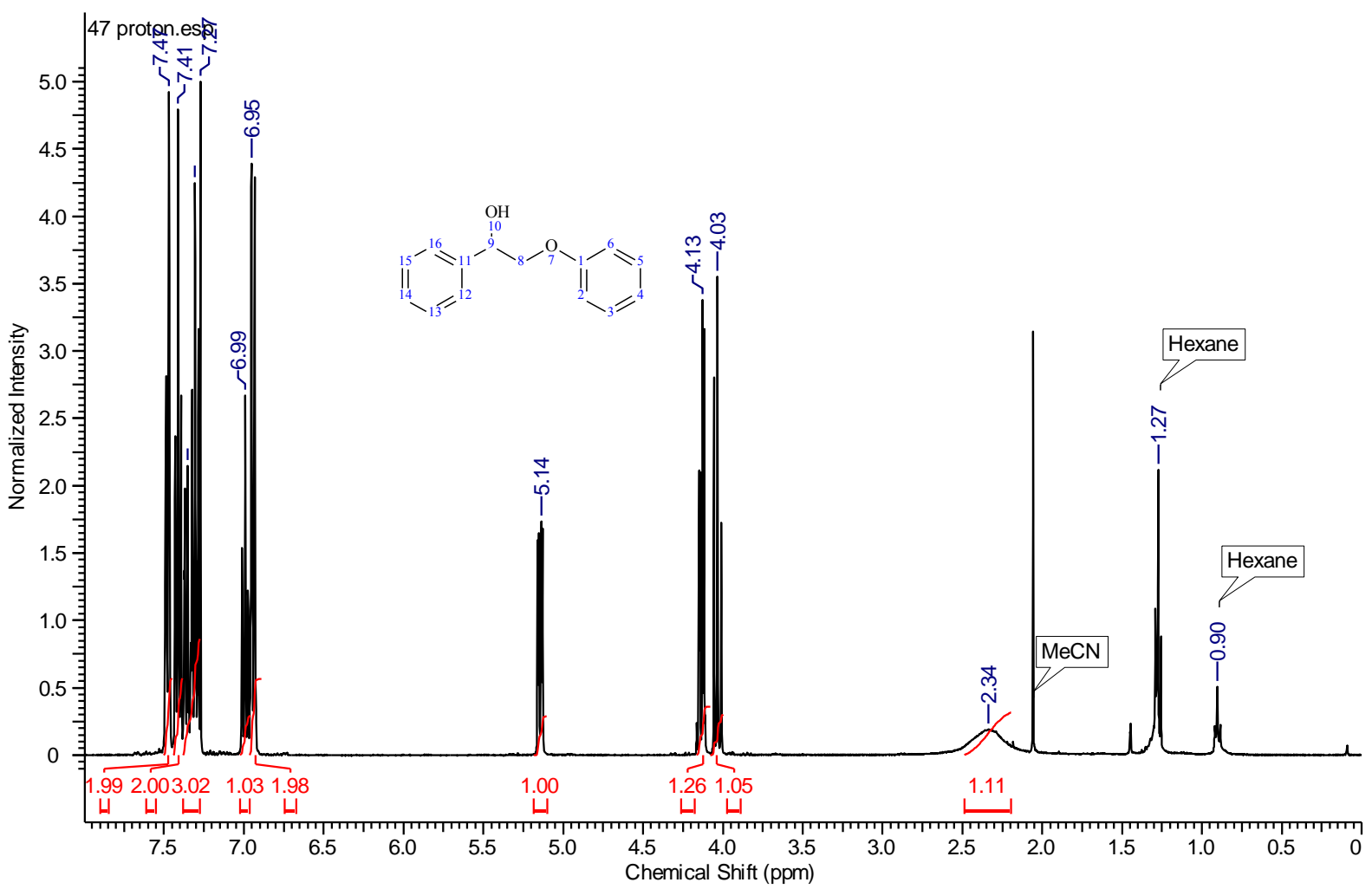

${ }^{13} \mathrm{C}$ NMR $\left(100 \mathrm{MHz}, \mathrm{CDCl}_{3}\right)-47$

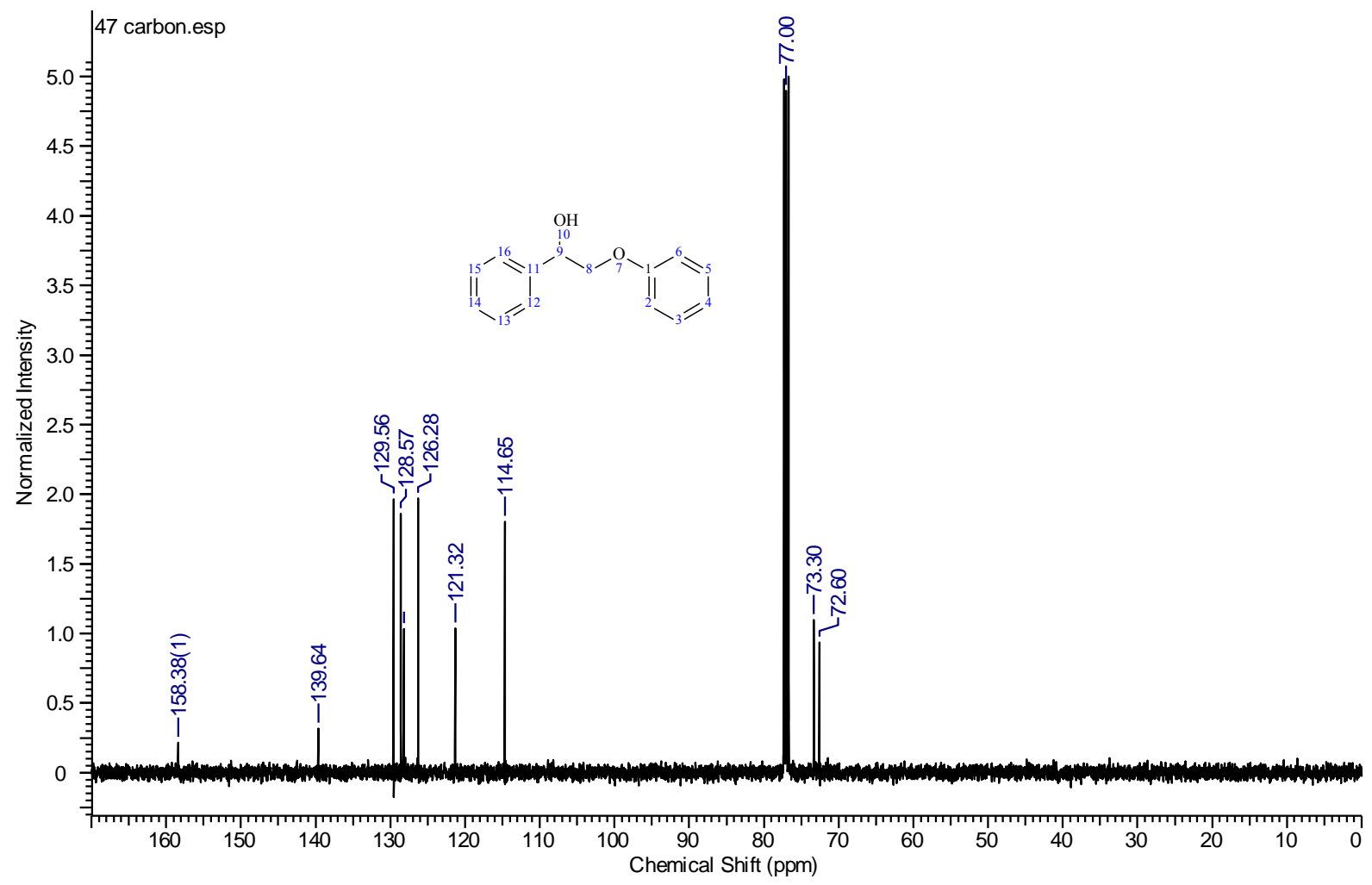

S21 
${ }^{1} \mathrm{H}$ NMR $\left(400 \mathrm{MHz}, \mathrm{CDCl}_{3}\right)-48$

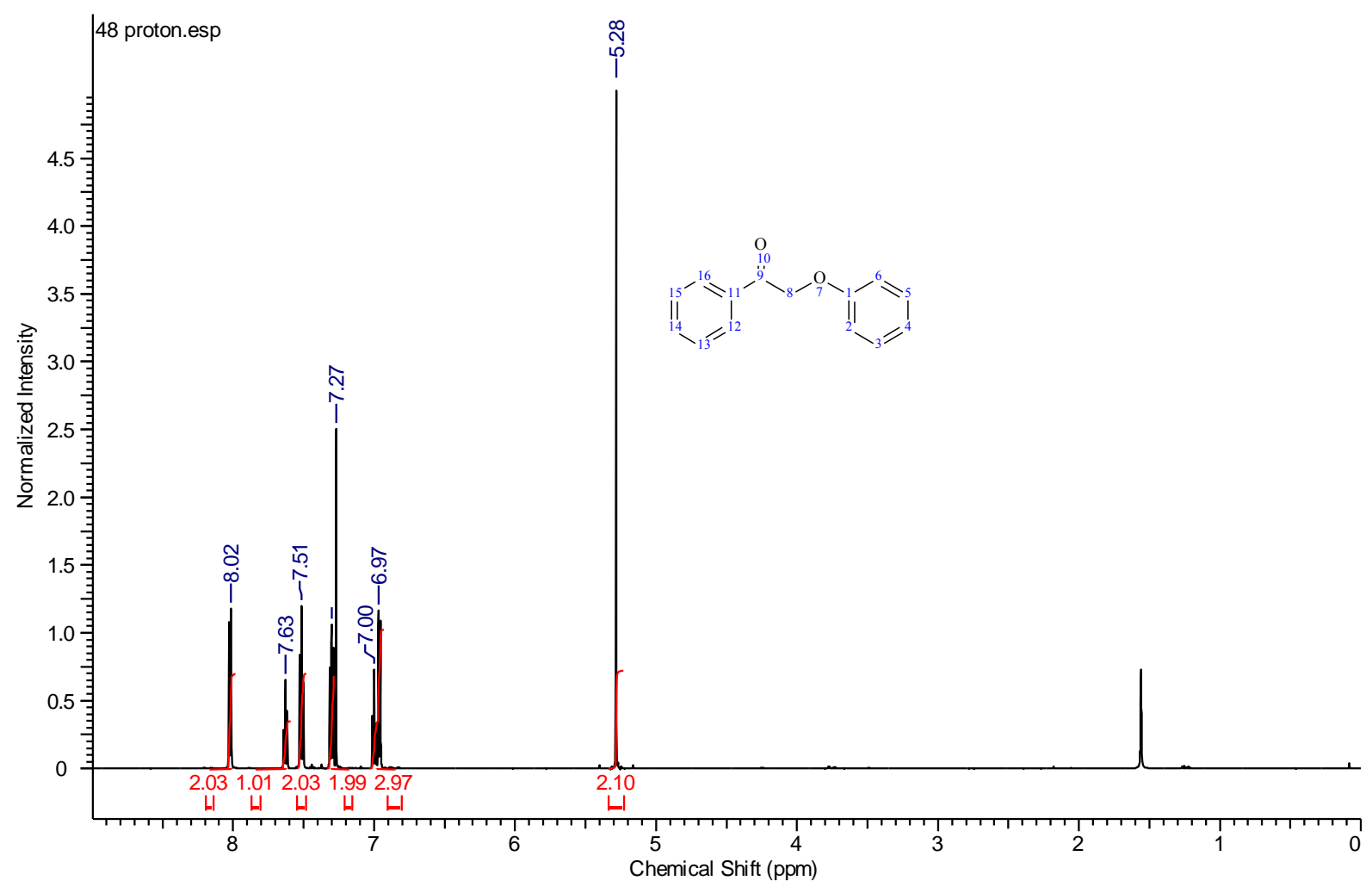

${ }^{13} \mathrm{C}$ NMR $\left(100 \mathrm{MHz}, \mathrm{CDCl}_{3}\right)-48$

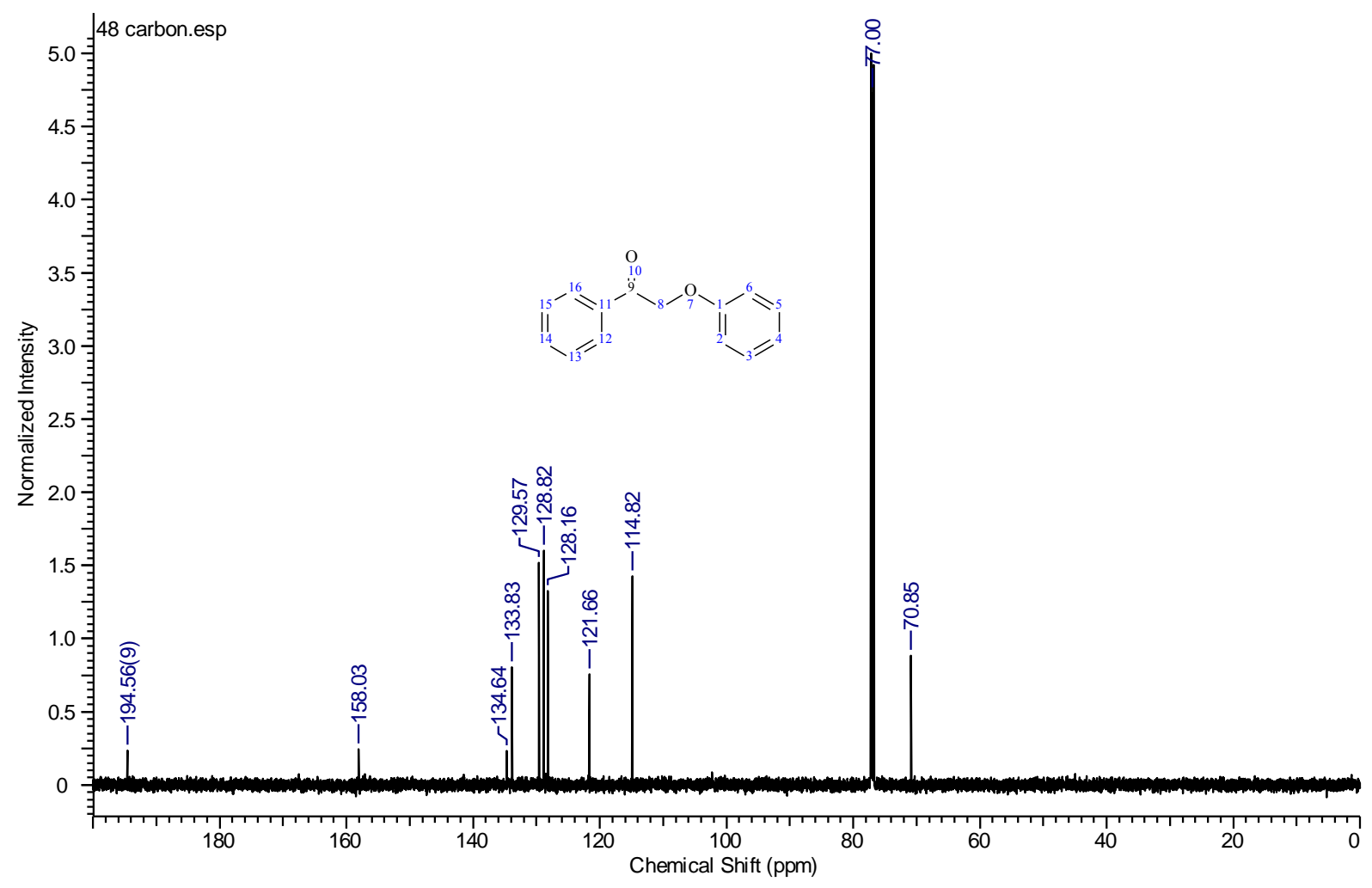

$\mathrm{S} 22$ 


\section{RefERences}

[1] H. Zhao, J. Label Compd. Radiopharm. 2008, 51, 293-296.

[2] Y. Wong, Q. Yang, Z. Zhou, H. K. Lee, T. C. W. Mak, D. K. P. Ng, New J. Chem. 2001, 25, 353-357.

[3] M. V Galkin, S. Sawadjoon, V. Rohde, M. Dawange, S. M. Samec, ChemCatChem 2014, 6, 179-184.

[4] S. Enthaler, B. Spilker, G. Erre, K. Junge, M. K. Tse, M. Beller, Tetrahedron 2008, 64, 38673876.

[5] K. Huang, M. Ortiz-Marciales, W. Correa, E. Pomales, X. Y. Lo, J. Org. Chem. 2009, 74, 4195-4202.

[6] A. R. Hajipour, S. A. Pourmousavi, A. E. Ruoho, Synth. Commun. 2008, 38, 2548-2566.

[7] X. Jia, L. Zhu, Q. Li, J. Li, D. Li, S. Li, J. Chem. Res. 2007, 203-204.

[8] Y. Wu, P. Y. Choy, F. Y. Kwong, Org. Biomol. Chem. 2014, 12, 6820-6823.

[9] L. C. McCann, M. G. Organ, Angew. Chem. Int. Ed. 2014, 53, 4386-4389.

[10] D. Saha, R. Ghosh, R. Dutta, A. K. Mandal, A. Sarkar, J. Organomet. Chem. 2015, 776, 8997.

[11] R. Pereira, J. Cvengroš, J. Organomet. Chem. 2013, 729, 81-85.

[12] Y. Zhu, B. Zhao, Y. Shi, Org. Lett. 2013, 15, 992-995.

[13] K. Walsh, H. F. Sneddon, C. J. Moody, Org. Lett. 2014, 16, 5224-5227.

[14] L. W. Deady, R. A. Shanks, A. D. Campbell, S. Y. Chooi, Aust. J. Chem. 1971, 24, 385-392.

[15] S. Mikami, S. Nakamura, T. Ashizawa, S. Sasaki, T. Taniguchi, I. Nomura, M. Kawasaki, Nitrogenated Heterocyclic Compound, 2015, EP2848618A1.

[16] M. Hatanaka, K. Takahashi, S. Nakamura, T. Mashino, Bioorganic Med. Chem. 2005, 13, 6763-6770.

[17] D. C. Horwell, M. C. Pritchard, Non-Peptide Bombesin Receptor Antagonists, 2001, US6194437B1.

[18] N. G. Connelly, W. E. Geiger, Chem. Rev. 1996, 96, 877-910.

[19] R. J. Enemærke, T. B. Christensen, H. Jensen, K. Daasbjerg, J. Chem. Soc. Perkin Trans. 2 2001, 1620-1630.

[20] C. P. Andrieux, C. Blocman, J. M. Dumas-Bouchiat, F. M'Halla, J. M. Savéant, J. Am. Chem. Soc. 1980, 102, 3806-3813. 